Araştırma Makalesi / Research Article

\title{
Sülfatça Zengin Killi Kayaların Dayanım ve Deformasyon Özellikleri ile Gevrek Kırılma Süreçleri
}

Strength and Deformation Properties of Sulphate-rich Clay Rocks and Their Brittle Failure Processes

\author{
Ömer ÜNDÜL ${ }^{1,2}$, Florian AMANN², Peter K. KAISER ${ }^{3}$ \\ ${ }^{1}$ İstanbul Üniversitesi, Jeoloji Mühendisliği Bölümü, Avcılar, ISTANBUL. \\ 5, 8092 Zurich, SWITZERLAND. \\ ${ }^{3}$ Center for Excellence in Mining Innovation, 936 Ramsey Lake Road, Sudbury P3E 6H5, CANADA.

$\begin{array}{lll}\text { Geliş (received) } & : & \text { 11 Kasım (November) } 2015 \\ \text { Düzeltme (revised) } & : & \text { 20 Aralık (December) } 2015 \\ \text { Kabul (accepted) } & : & \text { 22 Aralık (December) } 2015\end{array}$

${ }^{2}$ Swiss Federal Institute of Technology, Zurich, Institute of Geology, Engineering Geology, Sonneggstrasse

ÖZ

Sülfatça zengin killi kayalar üzerinde yapılan mühendislik çalışmalarında jips oluşumuna bağlı kabarmalar önemli sorunlara yol açmaktadır. Jips oluşumu genellikle, önceden varolan ve gerilim rahatlamaları sonucu genişleyen tektonik yapılara bağlı olarak veya çevresel gerilmeler etkisi ile oluşan mikroçatlakar boyunca gelişmektedir. Sülfatça zengin killi kayalar içerisinde yapılan yeraltı kazılarında, gerilmelerin, kırıklanma başlangıcı eşik değerini aşması durumunda, gevrek kırılma prensiblerine bağlı olarak deformasyon bölgeleri oluşmaktadır. Bu deformasyon bölgelerindeki mikroçatlakların, sülfatça zengin yeraltısularından jipsin çökelmesi için uygun koşulları sağlayacağı öne sürülmektedir. $\mathrm{Bu}$ çalışmada, sülfat içeriği yüksek killi kayaların yenilme mekanizmalarını açıklayabilmek için tek eksenli ve üç eksenli sıkışma testleri, akustik emisyon ve yüksek çözünürlüklü deformasyon ölçümleri, mikroyapısal ve mineralojik analizler ile birlikte gerçekleştirilmiştir. Çalışmada kullanılan örnekler İsviçre'nin kuzey kesimlerinde bulunan Belchen tünellerindeki Triyas yaşlı Gipskeuper formasyonundan alınmıştır. Çalışılan kaya birimi, tipik olarak belirgin killi seviyelerden, sert anhidrit damarlarından ve nodüllerinden oluşmaktadır. Çalışma sırasında, düşük deviatorik gerilme koşullarındaki yenilme davranışının, mikrokkırıkların ilk oluşmaya başladığı killi matriksin dayanımı ile kontrol edildiği ortaya konmuştur. Bunun yanında, artan deviatör gerilme veya şekil değiştirmeler ile, ilerleyen mikroçatlakların sağlam heterojen unsurlar tarafindan sınırlandırıldığı belirlenmiştir. Ayrıca mikrokırıklar, killi seviyeler ile sağlam heterojen yapıların arasındaki sınırı takip ederek gelişmekte veya artan gerilmeler ile daha sağlam heterojen yapıya (Anhidrit damarları) girmektedirler. Elde edilen bulgular daha büyük ölçekte değerlendirildiğinde, anhidrit tabakaları gibi sağlam heterojen yapıların ilerleyen kırıkları

Ö.Ündül

E-posta: oundul@istanbul.edu.tr 
Ündül, Amann, Kaiser

sınırlandırabileceği ve kaya kütlesinin hızlı bir şekilde parçalanmasını önleyeceği düşünülmektedir. Bu bağlamda, kaya kütlesinin, mikrokırıklanma başlangıcı eşik değerinin aşılmasından sonra zarar görmesine rağmen heterojen yapısından dolayı kendini tutabilecek olması, hızlı gelişen stabilite problemlerini önleyecektir.

Anahtar Kelimeler: Anhidrit, Gevrek Kırılma, Jips, Kil, Şişme.

\section{ABSTRACT}

Gypsum precipitation related heaving generates important problems in engineering studies conducted in sulphate rich clay rocks. Formation of gypsum is generally related to the relaxation of previously existing tectonic structures due to stress relief or are related to the microcracks formed by the effect of circumferential stresses. Depending on the brittle failure principals, deformation zones are generated in underground rock structures which are excavated in sulphate rich clay rocks due to the stresses exceeding the crack initiation stress level. It is suggested that these microcracks in deformation zones are preferential pathways for gypsum precipitation. In this study, to introduce the failure mechanisms of sulphate rich clay rocks, unconfined and confined compressive strength tests, acoustic emission tests and high resolution strain measurements were conducted including microstructural and mineralogical analysis. The samples used in the study were obtained from Gipskeuper formation of Triassic age from Belchen tunnels located in the northern parts of Switzerland. The unit is typically composed of distinct clay layers and stiff anhydrite veins and/or nodules. During the studies, it is concluded that the failure processes in low deviatoric stresses are controlled by the clay matrix where the microcracks are initiated. Besides, with increasing deviatoric stresses or strain the propagating microcracks are hindered by stiff heterogeneous structures. Furthermore microcracks propagates along the boundary between the clay matrix and the stiff heterogeneous structure or penetrates the stiff heterogeneous structures (anhydrite veins). By evaluating the data obtained for larger scale, it is suggested that the stiff heterogeneous structures like anhydrite veins can limit crack propagation and prevent disintegration of rock mass structure. In this respect, even the rock mass is terminated after excessing the crack initiation stress level, the heterogeneous structure hinders sudden failure of the rock mass.

Key Words: Anhydrite, Brittle failure, Gypsum, Clay, Heaving.

\section{GIIRIȘ}

İsviçre'nin kuzey kesimleri ile Almanya'nın güney-güney batı kesimlerinde bulunan Triyas yaşlı sülfatça zengin killi kayalarda yapılan mühendislik çalışmaları (tünel, otoyol vb.) sırasında ve yapıların mühendislik ömürleri boyunca pek çok sorun ile karşılaşılmaktadır. Sülfatça zengin killi kayalardaki bu sorunlar, 
şişme ve kabarmaya bağlı olabildiği gibi nadiren küçük ölçekli düşme ve kavlaklanmaya da bağlı olabilmektedir. Sülfatça zengin killi kayalarda yaşanan problemler dünyada pek çok yeraltı kazısında gözlenmiş ve farklı araştırmacılar tarafından değerlendirilmiştir. Çizelge 1'de bu konudaki benzer örneklerden bazıları sunulmuştur. yapım aşamasında şisme-kabarmaya bağl1 deformasyonlar birkaç hafta içerisinde onlarca santim boyutlara varmıştır (Grob, 1976). Belchen Tünelleri ve Tablo 1'de verilen tüneller pek çok defa yenileme ve tamir amaçlı olarak kapatılmak veya kontrollü olarak kullanılmak zorunda kalmıştır.

Çizelge 1. Sülfatça zengin killi kayalarda karşılaşılan şişme ve kabarma probleminin görüldüğü mühendislik projelerinden örnekler.

Table 1. Some engineering projects with swelling and heave problems due to sulphate rich clay rocks.

\begin{tabular}{lll}
\hline Tünel ismi & Ülke & Kaynak \\
\hline Hauenstein Tüneli & İsviçre & IGT, 1995 \\
\hline Bözberg Tüneli & İsviçre & Grob, 1976; Berdugo vd. 2009 \\
\hline Belchen Tüneli & İsviçre & $\begin{array}{l}\text { Grob, 1976; Nüesch vd. 1995; Amstad ve Kovari, } \\
\text { 2001; Amann vd. 2013a }\end{array}$ \\
\hline Weinsberg Tüneli & & Almanya \\
\hline Engelberg Tüneli & Almanya & Steiner vd. 2010 \\
\hline Wagenburg kuzey ve güney & Almanya & Berdugo vd. 2009 \\
Tünelleri & & \\
\hline Lilla Tüneli & İspanya & Berdugo vd. 2006; Alonso vd. 2013 \\
\hline Gezende Baraj1 & Türkiye & Oğuzberk, 2010 \\
\hline
\end{tabular}

$\mathrm{Bu}$ araştırma, $3.2 \mathrm{~km}$ uzunluğundaki çift tüplü Belchen Otoyol Tünellerine ait drenaj galerilerinde açılan sondajlardan elde edilen örnekler üzerinde gerçekleştirilmiştir (Şekil 1 ve 2). Söz konusu tünel, 1961-1969 yılları arasında Jura Dağları'nın, Basel (İsviçre) bölgesindeki kıvrımlı kesimlerinde inşaa edilmiştir. Tünel uzunluğunun yaklaşık yarısı, Triyas yaşlı sülfatça zengin, nadiren dolomit seviyeleri bulunan, anhidrit damarlı killi bir birim olan Gipskeuper formasyonu içinde kalmaktadır (Grob, 1972, Şekil 1 ve 2). Belchen Otoyol Tünelleri'nin
$\mathrm{Bu}$ çalışmada değerlendirilen sülfatça zengin killi kayalarda karşılaşılan problemlerin önemli bir kısmı, aşırı doygun sülfat çözeltilerinden jipsin çökelmesi ile oluşan, (Anagnostou vd., 2010; Alonso ve Berdugo, 2005; Vögtli ve Jordan, 1996) hacimsel artışa bağlı tünel tabanının kabarması şeklindedir. Bu kabarmalar, kazı aşamasından sonra tünel kaplamalarını patlatacak şekilde birkaç hafta veya birkaç ay içinde onlarca santimetreyi bulabilmektedir (Grob, 1976; Steiner ve Metzger, 1988; Steiner, 1993; Amstad ve Kovari, 2001). 
Ündül, Amann, Kaiser

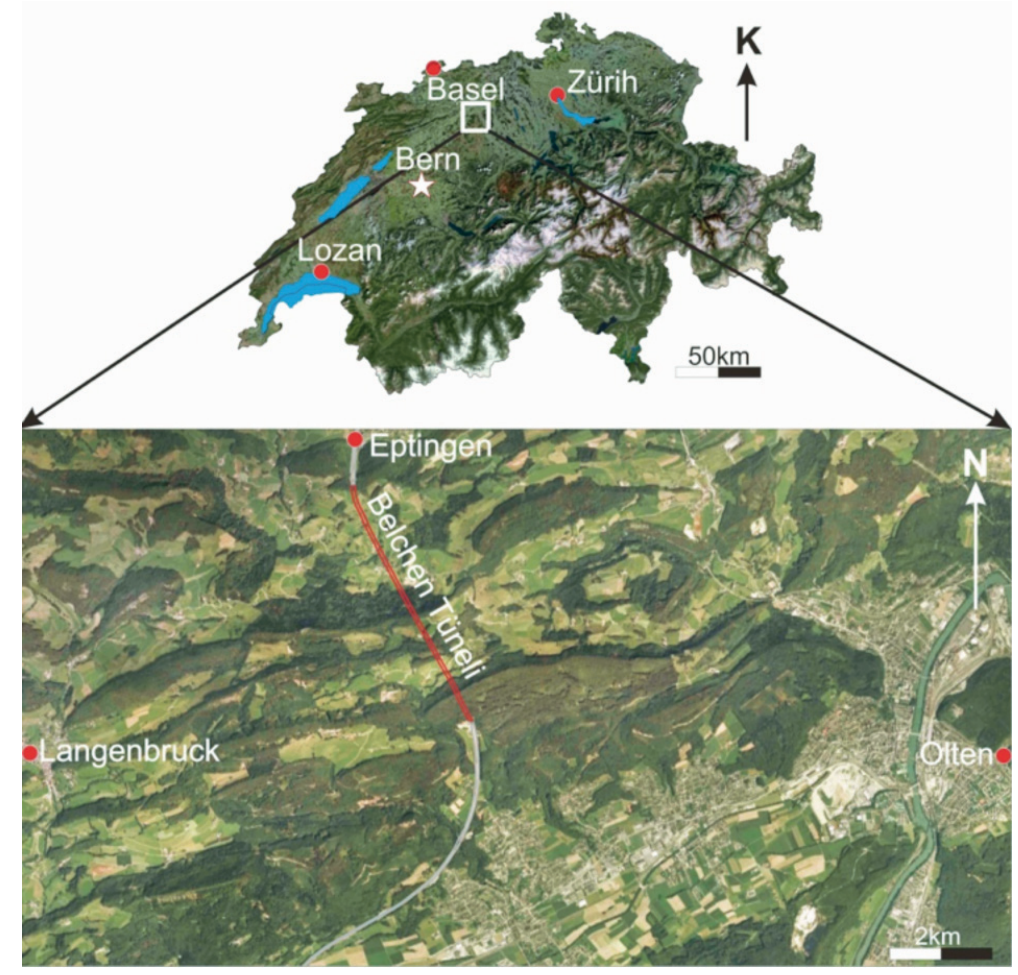

Şekil 1. Belchen Tüneli'ne ait yer bulduru haritası.

Figure 1. Location map of the Belchen Highway Tunnel.
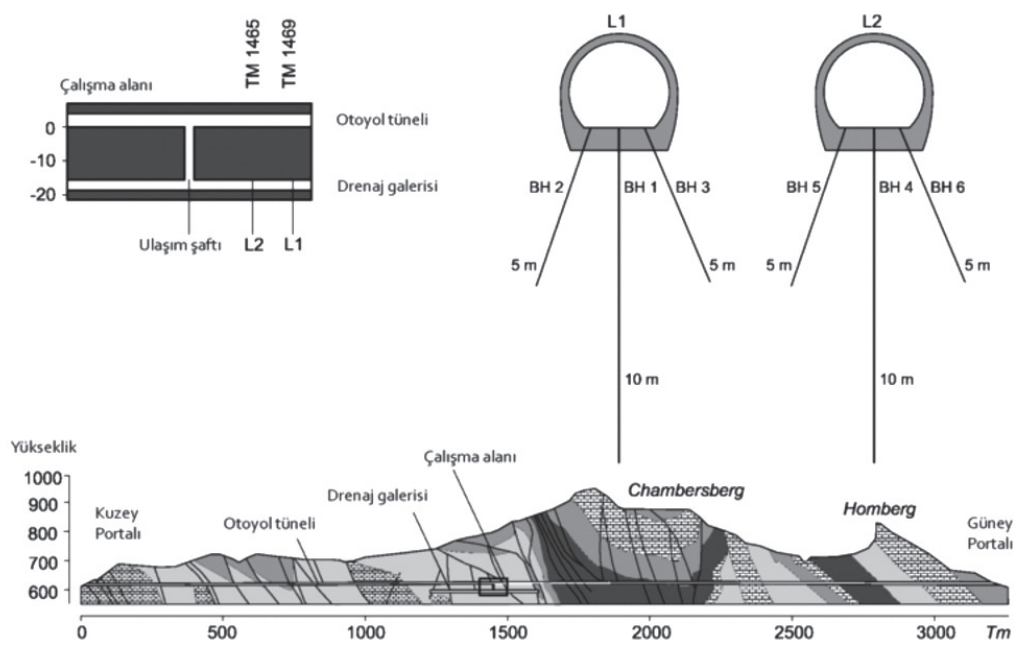

臨 Kirestaşı $\square$ Marn $\square$ Killi kayalar $\square$ Gipskeuper

Şekil 2. Belchen Otoyol Tüneli boyunca basitleştirilmiş jeolojik boyuna kesiti üzerinde sondaj yerlerinin gösterimi (Grob, 1976'dan sadeleştirilerek).

Figure 2. Borehole locations on the geological cross section along the Belchen Highway Tunnel (Simplified from Grob, 1976). 
Alonso ve Berdugo (2006), benzer kaya özelliklerinde açılmış tünellerde, tünel çevresindeki aşırı doygun yeraltı suyu koşullarının ve sülfatik killi kaya ortamlarının yenilme süreçleri hakkında detaylı bilgileri, jeomekanik ve mineralojik verilerin birlikte analiz edilmesi ile değerlendirmişlerdir. Yazarlar, bu ortamlardaki kaya yenilmelerini, mikroçatlakların açılması, hacim değişimine bağlı olarak dayanımın ve sertliğin azalması şeklindeki bir sıralama ile açıklamışlardır. Bunun yanında, jips çökeliminin mikroçatlaklar boyunca dolaşan sülfatça zengin yeraltı sularından kaynaklandığını gözlemlemişlerdir. Alonso ve Berdugo (2006), yeni gelişen süreksizliklerin gerilim degişimine bağlı olduğunu ve sülfatik killi kayalarda açılan tünellerde, bu bölgelerin jips oluşumu icin potansiyel çökelme alanları olacağı şeklinde yorumlamışlardır. $\mathrm{Bu}$ bulgular, Grob (1972), Madsen ve Nüesch (1991) ve Madsen vd. (1995)'in Belchen Otoyol Tünelleri'nde yaptıkları gözlemler ile uyumludur. Bu gözlemlerin yanısıra, Madsen ve Nüesch (1991), jips çökeliminin sülfat içermeyen kil tabakalarında da sıklıkla gelişebileceğini ortaya koymuşlardır. Grob (1972) de Belchen Tünelleri'nin jeolojik değerlendirmeleri sırasında, yeraltı suyu dolaşımının ve kristal gelişiminin deforme olmuş killer içindeki çok ince kırıklarda (hair line cracks) geliştiğini belirtmiştir.

Önceki çalışmalar, kil matris içindeki kırık, çatlak ve fissürlerin, veya daha önceden var olan tektonik yapıların, mühendislik çalışmalarına bağlı gerilim rahatlaması ile açılması (Alonso ve
Berdugo, 2008) sayesinde sülfatça zengin yeraltı suları için yeni akış güzergahlarının geliştiği ve jips çökelimi için uygun ortamlar oluştuğu yönünde birleşmektedirler. Ayrıca, tünel kazısı ile yeni kırıkların oluşabileceği ve böylece sülfatça zengin killi kayaların şişme potansiyellerinin artacağ 1 da Kaiser ve Kim (2008) tarafından öne sürülmüştür. Bunun yanında Steiner vd. (2010, 2011), gevrek kırılmaya bağlı açılma kırıklarının tünel altında hidrolik geçirgenliği arttıran bölgeler oluşturabileceğini, bunun da yeraltı suyu dolaşımını ve dolayısıyla jips çökelimi için uygun ön koşulları sağlayacağını öne sürmüşlerdir. Çalışma konusu olan kayalarda gevrek kırılma prensibinin uygulanması, tek eksenli gerilme koşulları altında kristalli kayalarda ve sedimanter kayalarda kırık gelişim süreçlerinin tariflenmesi çalışmalarına dayanmaktadır. Silindirik karot örneklerinde sıkışma deneyleri sonucunda gevrek kırılma, çatlaklanma başlangıcı, gelişimi ve bu kırıkların kritik seviyeye gelerek örneğin yenilmesi şeklinde açıklanmaktadır (Lockner vd., 1992). Tek eksenli yüklemelerde çatlaklanma başlangıcı tek eksenli sıkışma dayanımının yaklaşık $0.3-0.6$ oranındaki eksenel gerilme seviyelerinde gerçekleşmektedir (Brace vd., 1966; Hallbauer vd., 1973; Scholz, 1968; Martin ve Chandler, 1994; Nicksiar ve Martin, 2013). $\mathrm{Bu}$ çatlaklanmalar, başlangıçta çoğunlukla en yüksek gerilme yönüne paralel gelişmektedirler. Mikroçatlak gelişiminin ardından hacimsel genişleme gerçekleşse de mikroçatlaklar duraylı olarak genişlemektedirler (Bieniawski, 1967 ve Şekil 4). Artan gerilme ve şekil değiştirmeler ile mikroçatlaklar en yüksek dayanımın yaklaşık 0.7 
Ündül, Amann, Kaiser

- 0.9 oran1 seviyelerinde bir araya gelmektedir (Martin, 1997). Eksenel yükün daha da artmasıyla kritik kırık yoğunluğuna ulaşı1ır ve kaya örneği düşey çatlaklar oluşturarak yenilir (Şekil 4). $\mathrm{Bu}$ durum, yüksek çevre gerilmesi altında ise makaslama yenilmeleri şeklinde gelişmektedir. Tüneller etrafinda gelişen açılmalı kırıklar (tensile cracks) farklı kökenli kaya gruplarında gözlenmiştir (Kaiser ve Kim, 2008; Kaiser vd., 2010). gerilme seviyelerinin belirlenmesi amaçlanmış, ek olarak, mineralojik bileşim ve heterojenliğin kırıklanma süreçlerine ve dayanıma etkileri araştırılmıştır.

\section{YÖNTEMLER}

\section{Örneklerin alınması ve genel tanımları}

İsviçre Belchen Tünelleri drenaj galerilerinde açılan 6 adet sondaj kuyusundan

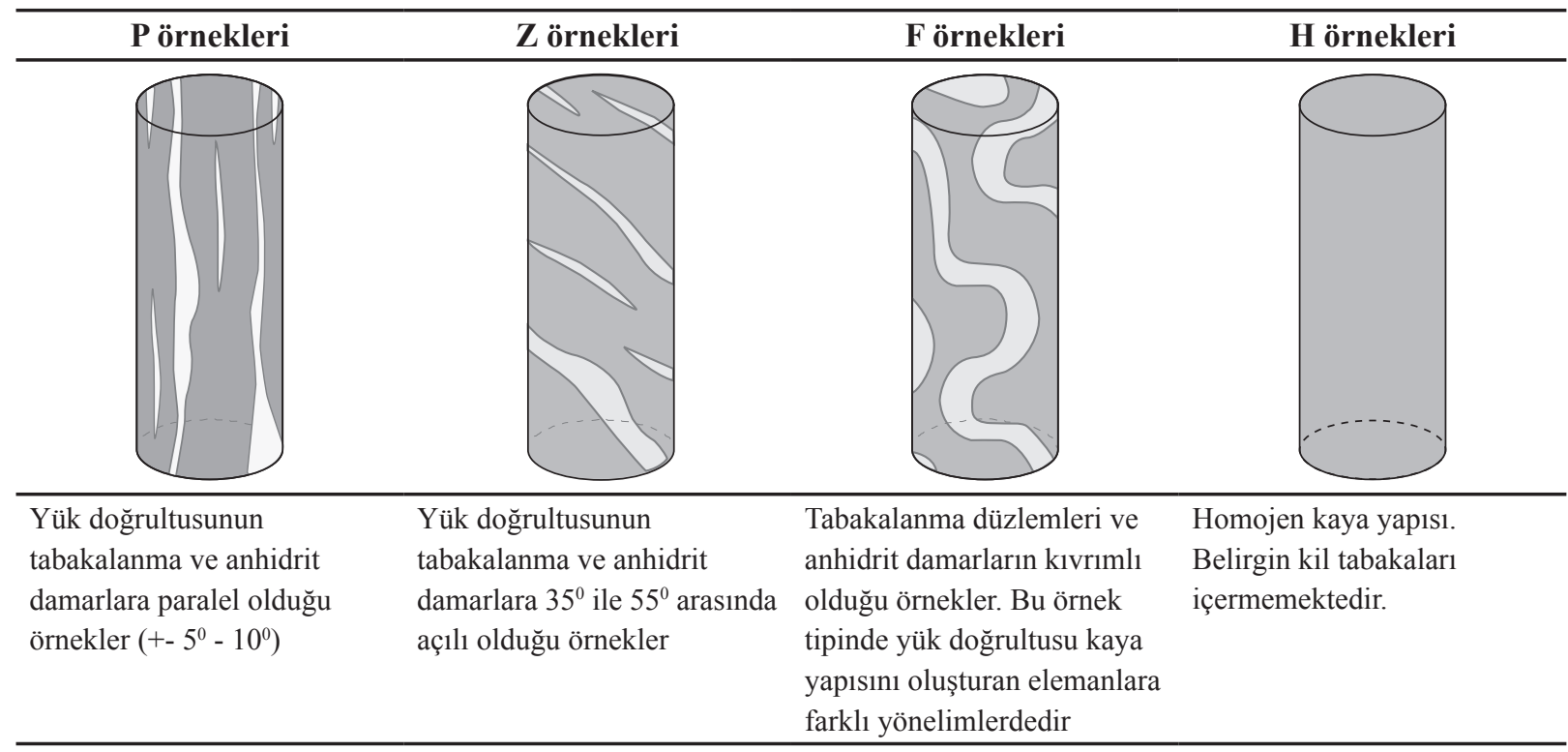

Şekil 3. Çalışma sırasında kullanılan örneklerin yük doğrultusuna göre şematik görünümleri ve örnek grupları.

Figure 3. The schematic view of specimens and sample groups with respect to loading direction.

Literatürdeki mevcut çalışmalara rağmen, sülfatça zengin killi kayaların gevrek yenilme süreçleri ve gevrek kırıklanmayı başlatacak gerilme seviyeleri hakkında iç yapının ele alındığı detaylı çalışmalar sınırlıdır. $\mathrm{Bu}$ çalışmada, sülfatça zengin killi kayaların çevre gerilmeli ve çevre gerilmesiz koşullarda yenilme davranışları ile mikroçatlaklanma başlangıcı elde edilen $84 \mathrm{~mm}$ çapındaki karot örnekleri, basınçlı hava soğutmalı çift tüplü karotiyerler ile alınmıştır. Yapılan sondajlardan dört tanesi 5'er metre ve 20 derece eğimli, diğerleri ise 10'ar metre ve düşey olarak açılmışlardır (Şekil 2). Karotların tamamı tanımlanmalarının ardından hava geçirmeyecek şekilde folyolara sarılmış ve vakumlanarak korumaya alınmıştır. 


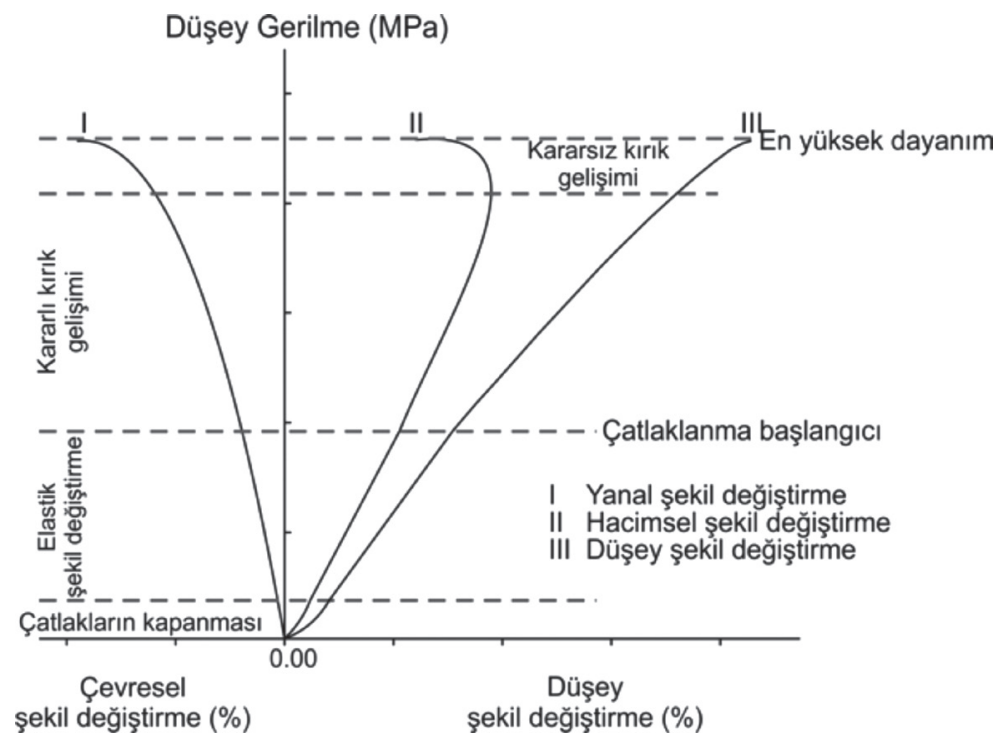

Şekil 4. Çevre gerilmesiz koşullarda, kayanın kırılma ve yenilme süreçlerinin gerilme - şekil değiştirme grafiğinde görünümü (Brace vd., 1966; Fairhurst ve Cook, 1966; Bieniawski, 1967; Scholz, 1968; Hallbauer vd., 1973; Lajtai, 1974; ve Tapponier ve Brace, 1976'dan değiştirilerek).

Figure 4. Stress-strain diagram of the fracturing and failure processes of rocks under unconfined compression conditions (Modified from Brace et al., 1966, Fairhurst and Cook, 1966; Bieniawski, 1967; Scholz, 1968, Hallbauer et al., 1973, Lajtai, 1974; Tapponier and Brace, 1976).

Örneklemenin yapıldığı birim çok sık ve çeşitli boyutlarda kıvırımlar ile çeşitli ölçeklerde fiziksel anizotropi özellikleri içermektedir. Farklı yönlerde tabakalanmalar gösteren karot örnekleri yüksek miktarda kil içeren (kil içeriği > \% 50) seviyelerden tamamen anhidrit/dolomit içeren (kil içeriği < \% 5) seviyelere kadar geniş bir mineralojik dağılım aralığı sunmaktadır. Farklı mineralojik bileşim ve çok degişken yönlerdeki tabakalanmalardan dolayı mekanik özellikler farklılık sunacağından karotlar Şekil 3’te verilen yönelimlere göre hazırlanmıştır.

Tek eksenli sıkışma dayanımı için farklı geometrik özelliklerde ve mineralojik bileşimlere göre temsilci örnekler hazırlanmıştır. Üç eksenli sıkışma dayanımı için ise sadece heterojen kaya yapısı (belirgin kil tabakaları ve sert heterojenlikler) olan örnekler seçilmiştir. Mekanik deneyler için örneklerin davranışının gerilim azalması, suda dağılma ve şisme/ kabarma süreçlerinden etkilenmemeleri için tünel taban kemerinin $2.5 \mathrm{~m}$ altından itibaren alınmıştır. Tek eksenli sıkışma dayanımı için 84 mm ve 34 mm çaplı örnekler, üç eksenli sıkışma dayanımı için ise sadece $34 \mathrm{~mm}$ çaplı örnekler kullanılmıştır. Tüm örnekler kuru koşullarda İsviçre Federal Teknoloji Enstitüsü Geoteknik Mühendisliği'nde elektronik kontrollü elmas testere (Type DRAMET BS 270) ile titreşimsiz olarak kesilmiştir. $0.7 \mathrm{~mm}$ inceliğindeki elmas testerenin dönme hızı 1200 metre/dk, ilerleme hızı ise $4 \mathrm{~mm} / \mathrm{dk}$ olarak ayarlanmıştır. Karot örneklerinin alt ve üst yüzeylerinin paralelliği ISRM (1979) tarafından önerilen değerleri 
Ündül, Amann, Kaiser

karşılamaktadır. Karot örnekleri hazırlanırken mümkün olduğunca hızlı çalışılmış ve her bir örnek hazırlama evresinde örnekler hava almayacak şekilde kaplanmıştır.

\section{Yerinde Görüntüleme Çalışmaları}

Sondaj deliklerinin açılmasından hemen sonra basınçlı hava ile temizlenmiş ve altı kuyuda Optik Görüntüleme (OPTV) işlemi başlatılmıştır. Sürekli olarak ve 360 derece gerçek renk kalitesinde sondaj deliği duvarları görüntülenmiştir. OPTV en yüksek çözünürlük

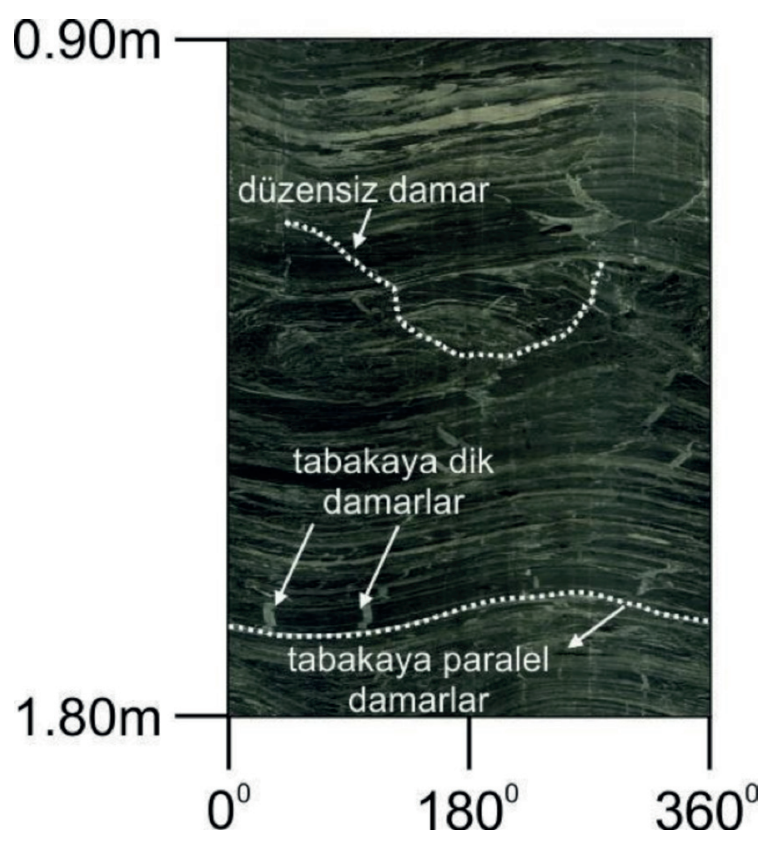

Şekil 5. B3 sondajı $0.90 \mathrm{~m}-1.80 \mathrm{~m}$ arasından elde edilmiş optik görüntülemeye ait görüntü üzerinde tabakalanmaya paralel, tabakaya dik ve rastgele yönlenmiş damarların görüntüsü.

Figure 5. The view of bedding parallel, bedding normal and random veins on optical teleview obtained from $B 3$ 0.90-1.80m. seviyesinde (düşey çözünürlük: $0.5 \mathrm{~mm} / \mathrm{piksel}$; yatay çözünürlük: $0.25 \mathrm{~mm} /$ piksel) çalıştırılmış ve sürekli olarak manyetik kuzey ile yönelimi kontrol edilmiştir.

Süreksizliklerin eğim - eğim yönleri vb. özelliklerinin analizleri, elde edilen görüntü boyunca sinisoidal bir görüntü veren süreksizliklerde WellCad (2.20) yazılımı ile gerçekleştirilmiştir. Santimetre mertebesinde ve düzensiz süreksizliklerin (Şekil 5) eğim ve eğim yönleri tespit edilemediğinden, bu gibi süreksizlikler gerekli görüldüğü yerlerde, detaylı karot analizleri yapılarak değerlendirilmiştir.

\section{Mineralojik Analizler}

Örneklere ait mineralojik bileşimler XRD analizleri yapılarak tespit edilmiştir. İlk olarak, örnekler, çeneli kırıcıda 0.4 mm'nin altındaki boyutlara getirilmiş ve homojenize edilmiştir. Ardından temsilci bir kısım ayrılarak McCrone mikronize değirmen ile tane boyu $20 \mu \mathrm{m}$ 'nin altına indirilmiştir. XRD ölçümleri BraggBrentano kırınım ölçeri (Philips PW1820) kullanılarak yapılmıştır. Toz örnekler oda sıcaklığında 2 ile 752Theta açıları arasında ölçülmüştür (basamak aralıkları $0.02^{\circ} 2$ Theta ve her bir basamak için zaman aralığ $14 s^{\prime}$ dir). Sayısal faz bileşimleri DIFFRACplus yazılımı kullanılarak belirlenmiştir. XRD ile elde edilen piklerin konumlarına ve birbirleri ile göreceli yoğunluklarına göre mineral fazları, Uluslarası Kırınım Verileri Merkezi'nin (ICSD) önerdiği formlar ile karşılaştırılarak belirlenmiştir. Ardından mineral bileşimleri Rietveld analiz 
yöntemine göre AutoQuan yazılımı kullanılarak tanımlanıştır.

\section{İnce kesit analizleri}

$\mathrm{Bu}$ çalışmada değerlendirilen ince kesitler hem mekanik deneylerden önce hem de mekanik deneylerden sonra hazırlanmıştır. İnce kesitler, mekanik deneylerde uygulanan yük doğrultusu gözetilerek test edilen her bir kaya örneği için hazırlanmıştır. İnce kesitlerin hazırlanmasından önce mavi renkli akışkan bir reçine örneğe emdirilmiştir. Böylece deney sonrası oluşan kırıkların daha kolay tespit edilmesi amaçlanmıştır. İnce kesitlerin tamamı kuru şartlarda hazırlanmıştır. İnce kesit görüntüleri Nikon Digital sight DS_U3 görüntüleme sistemi ve NIS Elements Imaging software 4.00 yazılımının desteklediği en yüksek çözünürlükte elde edilmiştir.

\section{Tek eksenli sıkışma dayanımı testleri}

Tek eksenli sıkışma dayanımı testleri İsviçre Federal Teknoloji Enstitüsü - Zürih (ETH) Mühendislik Jeolojisi Kürsüsü'nde 2000 kN kapasiteli servo-hidrolik kontrollü test cihazında gerçekleştirilmiştir. Eksenel ve çevresel deformasyon ölçerler şekil değiştirme ölçümlerinin örnek kenarlarındaki değişimlerden etkilenmemesi için örnek boylarının yarısı seviyelerine sıkıca yerleştirilmiştir. Eksenel deformasyon ölçerlerin örnek üzerindeki ölçüm aralığ 84 mm çaplı örnekler için 50 mm, 34 mm çaplı örnekler için ise $35 \mathrm{~mm}$ olarak belirlenmiştir. Çevresel şekil değiştirmeler (crad) ise örneğin etrafina sarılan zincire bağlı deformasyon ölçerler yardımıyla hesaplanmıştır (Şekil 6). Test sırasında dijital geri bildirim çevresel şekil değiştirme ile sağlanmış ve kullanılan kontrol değeri $0.05 \mathrm{~mm} / \mathrm{dk}$ olarak belirlenmiştir.

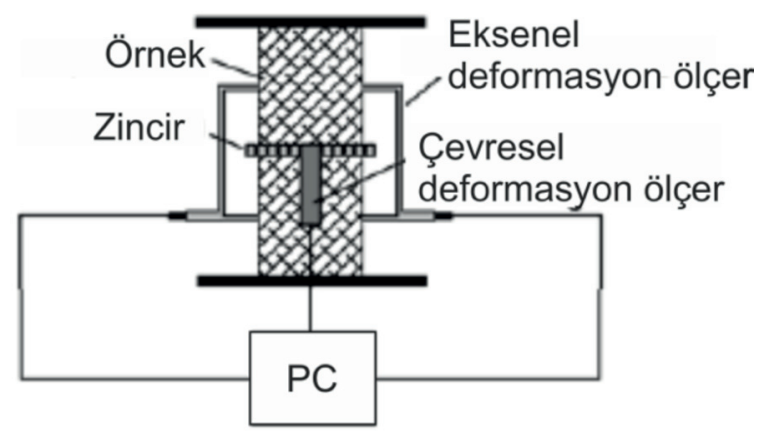

Şekil 6. Tek eksenli sıkışma dayanımı test düzeneğinin şematik görüntüsü (Amann vd., 2013a'dan değiştirilerek).

Figure 6. Shematic view of uniaxial compressive strength test (modified from Amann et al., 2013a).

\section{Üç eksenli sıkışma dayanımı testleri}

Üç eksenli sıkışma testleri İsviçre Federal Teknoloji Enstitüsü Lozan (EPFL) Üniversitesi Kaya Mekaniği Laboratuvarları'nda 2000 kN kapasiteli servo-hidrolik kontrollü ve dijital geri bildirim düzenekli test cihazında gerçekleştirilmiştir. Eksenel şekil değiştirmeler $20 \mathrm{~mm}$ LVDT (Linear Variable Differential Transformer - Doğrusal Değişkenli Fark Dönüştürücü) yardımıyla ölçülmüştür. $\mathrm{Bu}$ testler sırasında eksenel yer değiştirmeler geri bildirim sinyali olarak kullanılmış ve buradaki oran $0.01 \mathrm{~mm} / \mathrm{s}$ olarak belirlenmiştir. Test sırasında Hoek hücresindeki hacim değişimi 0.1 $\mathrm{cm}^{3}$ hassasiyetinde sürekli olarak ölçülmüştür. Hacimsel şekil değiştirmeler silindirik bir şekil 
Ündül, Amann, Kaiser

değiştirmenin olduğu varsayılarak, yağın hacim değişimlerinden yararlanılarak hesaplanmıştır. Üç eksenli sıkışma testlerinde 1, 2, 4 ve 8 MPa'lık çevre gerilmeleri uygulanmıştır. Deviatorik yükleme öncesinde eksenel yük ve çevresel gerilmeler sürekli olarak arttırılarak, belirlenmiş hidrostatik gerilme koşullarına gelmesi sağlanmıştır. Üç eksenli deneylerin gerçekleştirilmesine ait şematik görünüm Şekil 7'de verilmiştir.

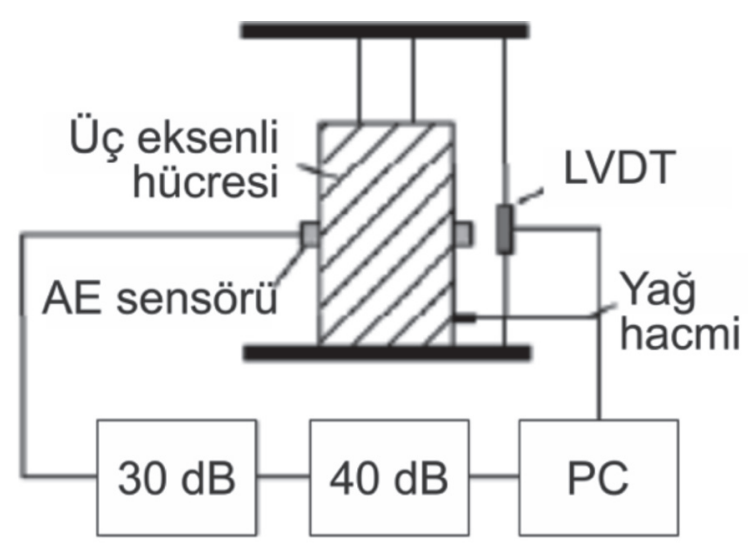

Şekil 7. Üç eksenli sıkışma dayanımı test düzeneğinin şematik görüntüsü (Amann vd., 2013a ve b'den değiştirilerek).

Figure 7. Schematic view of triaxial compressive strength test (modified from Amann et al., 2013a and 2013b).

\section{Yenilme başlangıcının belirlenmesi}

Gevrek kayalarda yenilme, mikroçatlaklanma ve yanal yenilmenin düşey yenilmeye oranla daha çok gelişmesi şeklinde tanımlanmaktadır. Kaya yenilmesinin başlangıcının belirlenmesi için gerilme - şekil değiştirme ve mikro ses aktivitesi özelliklerine göre farklı yöntemler önerilmiştir (Brace vd., 1966;
Bieniawski, 1967; Lajtai, 1974; Martin ve Chandler, 1994; Eberhardt vd., 1998; Nicksiar ve Martin, 2012).

Çevre gerilmesiz tek eksenli testlerde çatlaklanma başlangıcının ( $\sigma c 1)$ belirlenmesi için ölçülen deformasyon değerlerine göre değerlendirme esasına dayalı ve güvenilirlikleri Nicksiar ve Martin (2012) ve Amann vd. (2011) tarafından değerlendirilmiş iki yöntemden yararlanılmıştır. $\mathrm{Bu}$ yöntemlerden ilki Brace vd. (1966) tarafından önerilen ve temel olarak gerilme ve hacimsel deformasyon eğirisinin çizgisellikten saptığı andaki en düşük eksenel gerilme değeridir (Şekil 8a). Burada, hacimsel şekil değiştirme $\left(\varepsilon_{\mathrm{vol}}\right)$; iki eksenel şekil değişimin $\left(\varepsilon_{\text {axial }}\right)$ ortalaması ile çevresel şekil değiştirmenin $\left(\varepsilon_{\text {rad }}\right)$ iki katının toplanması şeklindedir (Formül $1)$.

$$
\varepsilon_{\mathrm{vol}}=\varepsilon_{\mathrm{axial}}+2 \varepsilon_{\mathrm{rad}}
$$

Kullanılan ikinci yöntem ise, Lajtai (1974) tarafından önerilen ve benzer prensiplerin çevresel şekil değiştirme eğrisine uygulanmasına dayanmaktadır (Şekil 8b). Bu yöntemde mikrokırıklanmanın başlangıcı, gerilme - çevresel şekil değiştirme eğrisinin çizgisellikten saptığ 1 nokta olarak ifade edilmektedir.

Çevre gerilmeli testlerde ise kırıklanma başlangıcı $(\sigma \mathrm{c})$, mikro ses aktivitesi yardımı ile Eberhardt vd. (1998)'in önerdiği yönteme göre Şekil 9‘da gösterildiği şekilde değerlendirilmiştir. Mikro ses aktiviteleri Euro Physical Acoustic (AE - akustik emisyon) sistemi yardımıyla ölçülmüştür. $10-10000 \mathrm{kHz}$ arasındaki hassiyette çalışan, iki adet $17 \mathrm{~mm}$ 
çaplı geniş bant aralıklı piezoelektrik algılayıcılar üç eksenli hücresine sıkıca takılmıştır (Şekil 7). Ses yükseltme işlemi iki aşamada yapılmıştır. Bunlardan ilki ön yükseltici ile $30 \mathrm{~dB}$ 'lik bir arttırmadır. Sinyal alıcıya ulaşmadan ikinci aşama yükseltici devreye girerek 40 dB'lik bir artış sağlanmaktadır. Verilerin kaydedilmesi önceden belirlenmiş sinyal büyüklüğünün aşılması durumunda gerçekleşmektedir. Böylece ses gürültüsü oluşturan düşük ses seviyelerine ait sinyallerin kaydedilmesi tamamen önlenemese de belirli ölçüde azaltılmaktadır.

Mikro-ses aktivitesinin yanı sıra, deviatorik yüklemeler sırasında yağ hacmindeki artış ve Hoek hücresindeki düşüşlerden yararlanılarak mikro-kırıklanmanın başladı̆̆ı gerilme değeri Brace vd. (1966) tarafindan önerilen yöntemden yararlanılarak tespit edilmiştir (Şekil 8a).
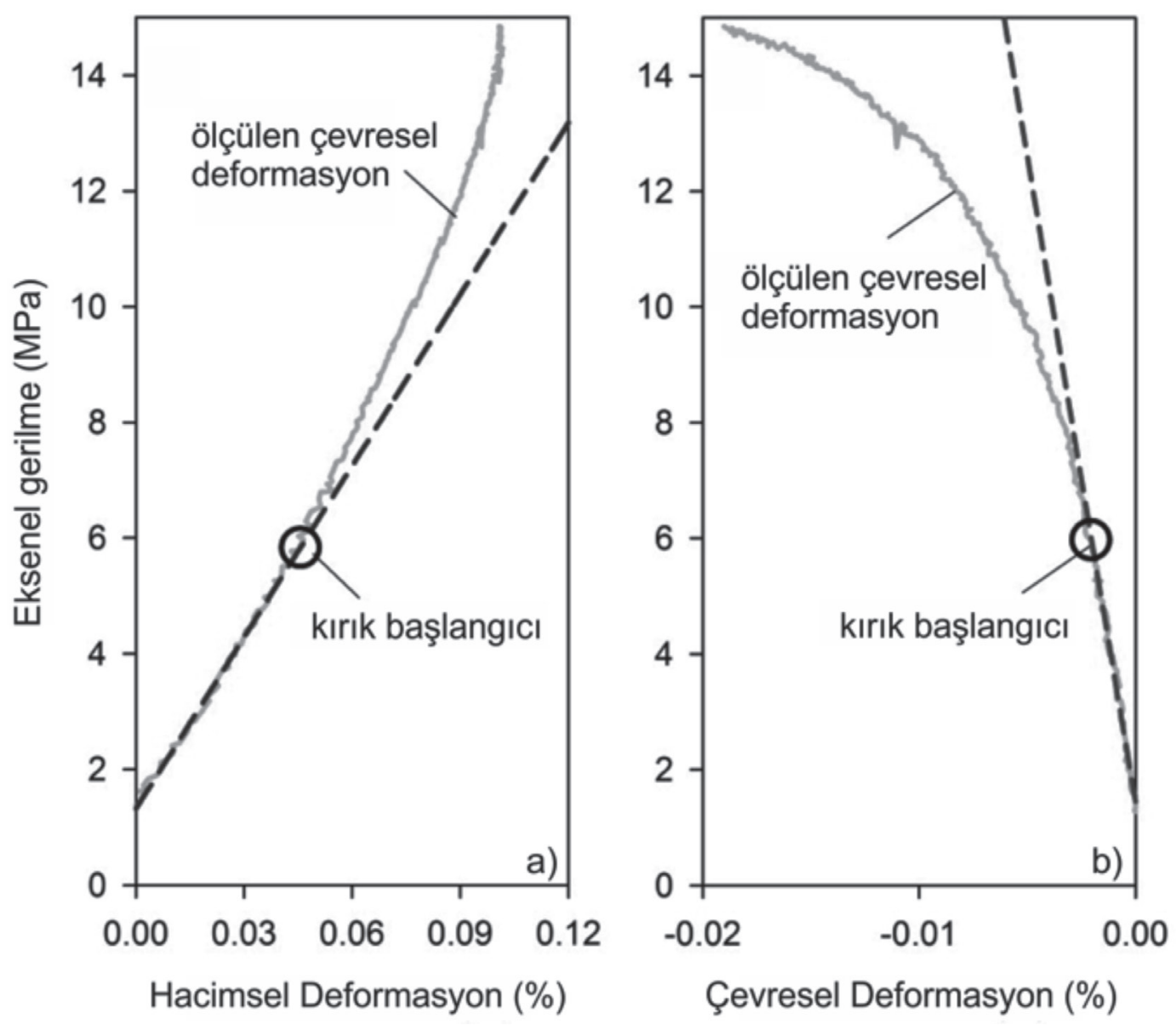

Şekil 8. Gcı'ın tespitinde kullanılan gerilme-şekil değiştirme diyagramları a) Brace vd. (1966) tarafından önerilen yöntem b) Lajtai (1974) tarafından önerilen yöntem.

Figure 8. The stress - strain diagrams utilized in determining the $\sigma c l$ a) Method proposedby Brace et a.l (1966) b) Method proposed by (Lajtai, 1974). 
Ündül, Amann, Kaiser

\section{BULGULAR VE TARTIŞMA}

Çalıșmalar sırasında elde edilen XRD sonuçları Çizelge 2'de, mekanik deneylere ait sonuçlar ise Çizelge 3'te (tek eksenli sıkışma dayanımı deneyi) ve Çizelge 4'te (üç eksenli sıkışma dayanımı deneyi) verilmektedir.

Çizelge 2. Tek eksenli sıkışma dayanımı testlerinde kullanılan örneklere ait XRD verileri.

Table 2. XRD data of the specimens used in the uniaxial compressive strength test.

\begin{tabular}{|c|c|c|c|c|c|c|c|c|}
\hline $\begin{array}{c}\text { Kuyu } \\
\text { Numaras } \\
(-)\end{array}$ & $\begin{array}{c}\text { Derinlik } \\
(\mathrm{cm})\end{array}$ & $\begin{array}{l}\text { Ah } \\
(\%)\end{array}$ & $\begin{array}{l}\text { Gy } \\
(\%)\end{array}$ & $\begin{array}{l}\text { Ba } \\
(\%)\end{array}$ & $\begin{array}{l}\text { Do } \\
(\%)\end{array}$ & $\begin{array}{c}\mathbf{Q} \\
(\%)\end{array}$ & $\begin{array}{l}\text { Mg } \\
(\%)\end{array}$ & $\begin{array}{l}\mathbf{C M} \\
(\%)\end{array}$ \\
\hline B3 & 330 & 49.17 & 0.15 & 0 & 0 & 4.23 & 9.68 & 28.72 \\
\hline B4 & 287 & 20.28 & 0.63 & 0.22 & 0.68 & 3.49 & 15.91 & 46.23 \\
\hline B4 & 630 & 35.07 & 7.77 & 0 & 1.29 & 5.78 & 9.38 & 30.75 \\
\hline B3 & 335 & 37.76 & 0.86 & 1.15 & 0 & 5.15 & 14.65 & 25.07 \\
\hline B3 & 318 & 51.29 & 0.83 & 1.37 & 0 & 10.23 & 8.59 & 17.85 \\
\hline B3 & 270 & 57.4 & 0.52 & 1.71 & 0 & 5.2 & 7.73 & 16.54 \\
\hline B3 & 445 & 36.86 & 0.64 & 1.75 & 0.69 & 2.85 & 8.82 & 39.74 \\
\hline B1 & 687 & 30.62 & 4.11 & 0.17 & 0.2 & 9.08 & 25.58 & 20.69 \\
\hline B1 & 385 & 53.89 & 1.05 & 1.36 & 0 & 6.96 & 10.21 & 16.98 \\
\hline B1 & 505 & 65.3 & 0 & 0.16 & 0 & 1.8 & 19.6 & 8.58 \\
\hline B5 & 485 & 45.91 & 1.59 & 0.94 & 0.39 & 5.31 & 18.98 & 16.07 \\
\hline B4 & 257 & 58.94 & 0.44 & 1.32 & 0 & 6.13 & 14.55 & 10.76 \\
\hline B3 & 412 & 47.94 & 0.91 & 0.91 & 0 & 7.15 & 25.81 & 8.57 \\
\hline B3 & 420 & - & - & - & - & - & - & - \\
\hline B1 & 495 & 69.3 & 0 & 1.78 & 0 & 2.03 & 11.56 & 9.31 \\
\hline B4 & 250 & 70.49 & 0.22 & 1.57 & 0 & 3.57 & 10.89 & 7.24 \\
\hline B3 & 450 & 67.61 & 0.36 & 1.36 & 0 & 2.3 & 14.28 & 9.52 \\
\hline B1 & 795 & 46.35 & 0.52 & 2.13 & 43.87 & 1.31 & 0.05 & 4.4 \\
\hline B1 & 810 & 57.38 & 0.52 & 1.66 & 30.19 & 1.41 & 0.07 & 3.69 \\
\hline B1 & 710 & 80.41 & 0.16 & 1.8 & 12.29 & 0.48 & 0.13 & 2.87 \\
\hline B1 & 720 & 84.23 & 0.36 & 1.91 & 7.84 & 0.26 & 0.12 & 2.97 \\
\hline
\end{tabular}

Ah: Anhidrit; Gy: Jips; Ba: Basanit; Do: Dolomit; Q: Kuvars; Mg: Manyezit; CM: Kil mineralleri. (Smektit, illit ve klorit minerallerinin toplamı verilmiştir). 
Çizelge 3. Tek eksenli sıkışma dayanımı deneyi sonuçları.

Table 3. The results of uniaxial compressive strength tests.

\begin{tabular}{|c|c|c|c|c|c|c|c|c|}
\hline $\begin{array}{c}\text { Kuyu } \\
\text { numarası } \\
(-) \\
\end{array}$ & $\begin{array}{c}\text { Derinlik } \\
(\mathrm{cm}) \\
\end{array}$ & $\begin{array}{c}\text { Örnek tipi } \\
(-)\end{array}$ & $\begin{array}{c}D \\
(\mathrm{~mm}) \\
\end{array}$ & $\begin{array}{c}E \\
\text { (GPa) } \\
\end{array}$ & $\begin{array}{l}v \\
(-) \\
\end{array}$ & $\begin{array}{c}\text { UCS } \\
\text { (MPa) } \\
\end{array}$ & $\begin{array}{c}\sigma_{\mathrm{CI}}(\mathrm{I}) \\
(\mathrm{MPa})\end{array}$ & $\begin{array}{l}\sigma_{\mathrm{CI}}(\mathrm{II}) \\
(\mathrm{MPa}) \\
\end{array}$ \\
\hline B3 & 330 & Z & 34 & 2.8 & 0.13 & 5.6 & 4.0 & 3.8 \\
\hline B4 & 287 & $\mathrm{P}$ & 34 & 5.2 & 0.08 & 6.6 & 4.0 & 4.4 \\
\hline B4 & 630 & Z & 84 & 4.9 & 0.09 & 7.7 & 4.0 & 3.8 \\
\hline B3 & 335 & Z & 34 & 6.4 & 0.17 & 7.8 & 4.6 & 4.2 \\
\hline B3 & 318 & $\mathrm{~F}$ & 34 & 6.1 & 0.09 & 11.9 & 6.6 & 6.4 \\
\hline B3 & 270 & $\mathrm{~F}$ & 84 & 9.4 & 0.04 & 16.1 & 6.5 & 6.5 \\
\hline B3 & 445 & $\mathrm{P}$ & 34 & 42.2 & 0.16 & 20.1 & 15.2 & 12.9 \\
\hline B1 & 687 & $\mathrm{P}$ & 34 & 12.4 & 0.06 & 23.5 & 7.9 & 8.1 \\
\hline B1 & 385 & $\mathrm{~F}$ & 34 & 29.7 & 0.19 & 25.5 & 12.4 & 12.1 \\
\hline B1 & 505 & $\mathrm{~F}$ & 34 & 33.1 & 0.21 & 28 & 9.9 & 9.2 \\
\hline B5 & 485 & $\mathrm{P}$ & 84 & 35.3 & 0.07 & 32.6 & 10.5 & 7.7 \\
\hline B4 & 257 & $\mathrm{~F}$ & 34 & 26.1 & 0.09 & 41.2 & 13.7 & 13.7 \\
\hline B3 & 412 & $\mathrm{P}$ & 34 & 65 & 0.18 & 44.6 & 22.1 & 22.4 \\
\hline B3 & 420 & $\mathrm{P}$ & 34 & 80.7 & 0 & 46.8 & - & - \\
\hline B1 & 495 & $\mathrm{~F}$ & 34 & 36.1 & 0.11 & 52.6 & 17.4 & 13.4 \\
\hline B4 & 250 & $\mathrm{~F}$ & 34 & 32.4 & 0.06 & 64.2 & 19.5 & 19.7 \\
\hline B3 & 450 & $\mathrm{P}$ & 34 & 68.8 & 0.16 & 71.7 & 45.5 & 40.0 \\
\hline B1 & 795 & $\left.\mathrm{H}^{*}\right)$ & 34 & 84.3 & 0.21 & 75.4 & 63.5 & 61.0 \\
\hline B1 & 810 & $\left.\mathrm{H}^{*}\right)$ & 34 & 77 & 0.21 & 83 & 72.5 & 63.5 \\
\hline B1 & 710 & $\left.\mathrm{H}^{*}\right)$ & 34 & 85.7 & 0.2 & 93.6 & 67.5 & 55.0 \\
\hline B1 & 720 & $\left.\mathrm{H}^{*}\right)$ & 34 & 80.2 & 0.21 & 150.9 & 89.5 & 85.5 \\
\hline
\end{tabular}

Z: Z tipi örnekler; P: P tipi örnekler; F: F tipi örnekler; H: homojen örnekler; $D$ : örnek çapı; $E$ : Young Modülü; $v$ : Poisson oranı; UCS: tek eksenli sıkışma dayanımı; $\sigma_{\mathrm{CI}}$ (I): Brace vd. (1966)'nın önerdiği yönteme göre hesaplanan çatlaklanma başlangıcı gerilme değeri; $\sigma_{\mathrm{CI}}$ (II): Lajtai (1974)'ün önerdiği yönteme göre hesaplanan çatlaklanma başlangıc1 gerilme değeri.

$\mathrm{H}^{*}$ belirgin kil bantı içermeyen homojen örnek tipi. 
Ündül, Amann, Kaiser

Çizelge 4. Üç eksenli sıkışma dayanımı deneyi sonuçları.

Table 4. The results of triaxial compressive strength tests.

\begin{tabular}{|c|c|c|c|c|c|c|c|c|c|}
\hline $\begin{array}{c}\text { Kuyu } \\
\text { numarası } \\
(-)\end{array}$ & $\begin{array}{c}\text { Derinlik } \\
\text { (cm) }\end{array}$ & $\begin{array}{c}\text { Örnek tipi } \\
(-)\end{array}$ & $\begin{array}{c}D \\
(\mathrm{~mm})\end{array}$ & $\begin{array}{c}E \\
\text { (GPa) }\end{array}$ & $\begin{array}{l}v \\
(-)\end{array}$ & $\begin{array}{r}s_{3} \\
(\mathrm{MPa})\end{array}$ & $\begin{array}{r}s_{1, \text { peak }} \\
\text { (MPa) }\end{array}$ & $\begin{array}{r}\sigma_{C I, A E} \\
\text { (MPa) }\end{array}$ & $\begin{array}{r}\sigma_{C I, v o l} \\
\text { (MPa) }\end{array}$ \\
\hline B4 & 330 & Z & 34 & 14.5 & 0.14 & 8 & 71.5 & 15.0 & 13.9 \\
\hline B1 & 270 & Z & 34 & 12.1 & 0.30 & 2 & 39.9 & 8.2 & 8.3 \\
\hline B3 & 249 & Z & 34 & 24.2 & 0.10 & 2 & 46.9 & 8.4 & 9.5 \\
\hline B4 & 267 & Z & 34 & 5.4 & 0.31 & 1 & 44.7 & 8.6 & - \\
\hline B4 & 335 & Z & 34 & 22.3 & 0.37 & 1 & 31 & 6.2 & - \\
\hline B4 & 335 & Z & 34 & 10.1 & 0.30 & 2 & 42 & 6.1 & 6.5 \\
\hline B4 & 405 & $\mathrm{P}$ & 34 & 11.2 & 0.20 & 8 & 53.7 & 15.6 & 16.2 \\
\hline B3 & 440 & $\mathrm{P}$ & 34 & 12.3 & 0.07 & 2 & 43.2 & - & 7.7 \\
\hline B4 & 275 & $\left.\mathrm{P}^{*}\right)$ & 34 & 25.8 & 0.08 & 8 & 101 & 15.7 & 15.8 \\
\hline B3 & 455 & $\mathrm{~F}$ & 34 & 29.9 & 0.31 & 8 & 93.8 & 14.5 & 16.6 \\
\hline B3 & 245 & $\left.\mathrm{P}^{*}\right)$ & 34 & 25.8 & 0.27 & 1 & 67.3 & 7.1 & 7.3 \\
\hline B3 & 231 & $\mathrm{~F}$ & 34 & 32.1 & 0.10 & 4 & 89.8 & 10.5 & 11.6 \\
\hline B3 & 227 & $\mathrm{P}$ & 34 & 37.4 & 0.16 & 4 & 112 & 11.9 & 12.0 \\
\hline B5 & 505 & $\mathrm{P}$ & 34 & 64.9 & 0.19 & 2 & 116.3 & 9.6 & 10.0 \\
\hline B4 & 495 & $\mathrm{P}$ & 34 & 62 & 0.10 & 1 & 99 & - & - \\
\hline
\end{tabular}

Z: Z tipi örnekler; P: P tipi örnekler; F: F tipi örnekler; D: örnek çapı; E: Young Modülü; v: Poisson oranı; s3: çevre gerilmesi; s1, peak: en yüksek dayanım; $\sigma_{\mathrm{Cl}}$, AE: mikro ses aktivitesi ile belirlenen çatlaklanma başlangıcındaki eksenel yük; $\sigma_{\mathrm{Cl}}$, vol: Brace vd. (1966)'nın önerdiği yönteme göre belirlenen çatlaklanma başlangıcındaki eksenel yük.

$\mathrm{P}^{*)}$ süreksiz sert damarlar içeren P tipi örnekler.

Tek eksenli deney sonuçlarının mineralojik ve petrografik özellikler ile ilişkileri

Deneyler sırasında elde edilen sonuçlara göre, incelenen kayaların tek eksenli sıkışma dayanımı değerleri 5.6 MPa ile $151 \mathrm{MPa}$ arasında değişmektedir. Düşük dayanım değerleri, kil matriks boyunca yenilen örneklerden, yüksek değerler ise, \% 84'e varan anhidrit içeriğine sahip H tipi örneklerden elde edilmiştir. Düşük eksenel gerilmelerde eksenel şekil değiştirme eğrisinden elde edilen Young modülü 2.8 - 85.7 $\mathrm{GPa}$ arasında değişmektedir. Poisson oranı ise $0.06-0.21$ aralığındadır 


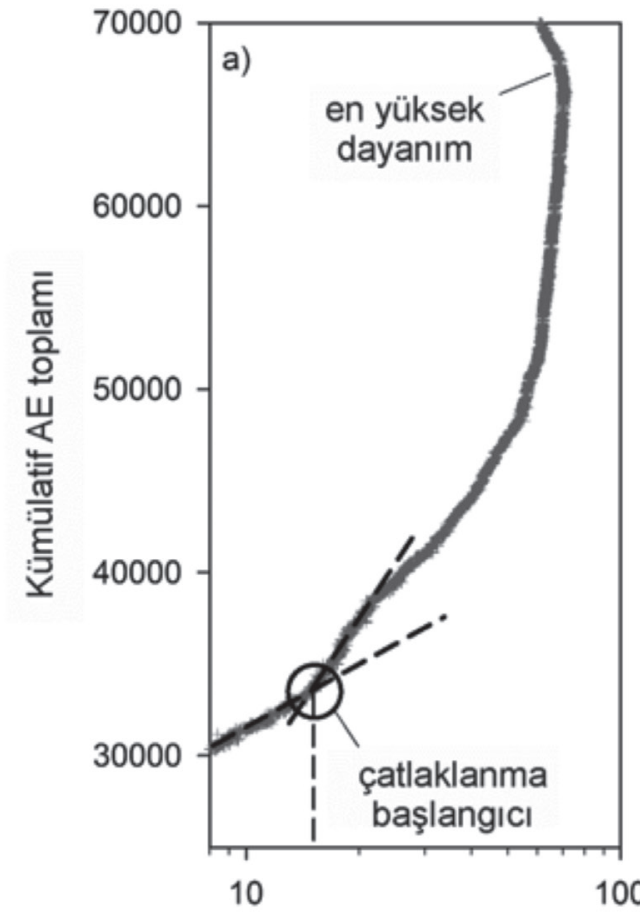

Eksenel Gerilme (MPa)

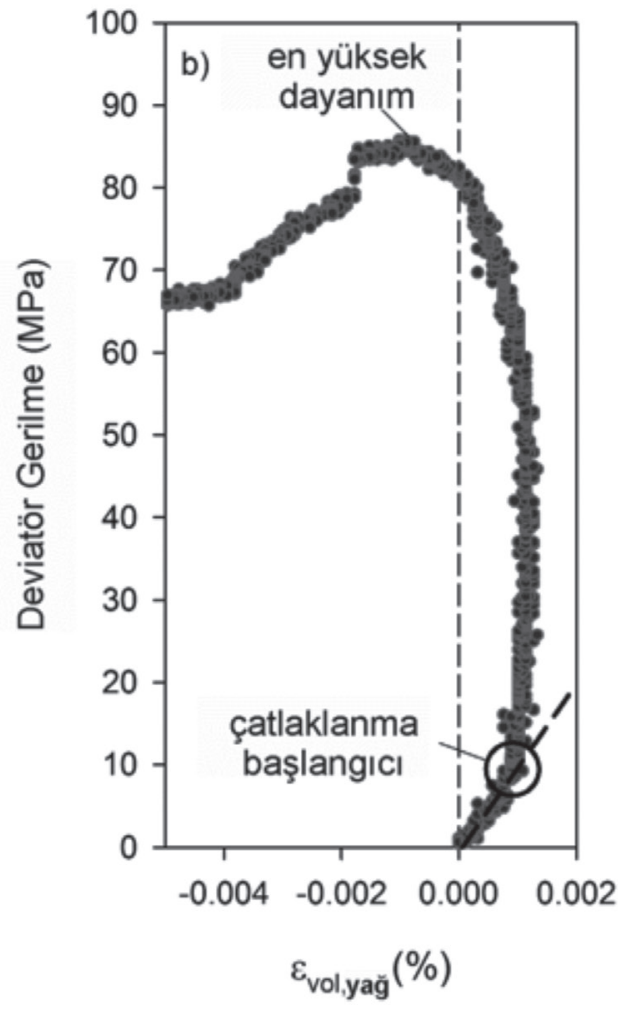

Şekil 9. Çevre gerilmeli koşullarda, $\sigma$ cı’ın tespitinde kullanılan yöntemler a) mikro ses aktivitesine ait grafik (Eberhardt vd. 1998'in önerdiği yönteme göre). b) Hoek hücresinin deviatorik yüklemede yağ alıp vermesi ile gelişen hacim değişimine ait grafik. Şekildeki kesikli çizgiler düşük deviatorik gerilmelerdeki çizgisel gidişi göstermektedir.

Figure 9. Methods used in defining $\sigma_{c l}$ under confined conditions a) the graph of acoustic emission (based on Eberhardt et al. 1998) b) the volumetric strain response obtained from oil-volume gain or loss in the Hoek cell during deviatoric loading. The dashed line in b represents the linear trend at low deviatoric stress.

UCS (Uniaxial Compressive Strength - Tek Eksenli Sıkışma Dayanımı) ile $\sigma_{C I}$ arasındaki ilişki Şekil 10'da gösterilmektedir. Tek eksenli sıkışma dayanımının 5.6 ila $65 \mathrm{MPa}$ arasındaki seviyede $\sigma_{C r}$ UCS'e göre 3:10 oranında artmaktadır (Şekil 10). UCS bu aralıkta olduğu durumda, kırıklanma başlangıcı değerleri 4-13 $\mathrm{MPa}$ arasında değişmektedir. UCS'in 65-75 MPa arasında olduğu durumda, $\sigma_{C I}$ önemli bir şekilde artış göstermiştir. Bu UCS değerinin üzerinde $(\mathrm{H}$ örnekleri), $\sigma_{C I}$, benzer şekilde yine $U C S$ 'e göre 3:10 oranında artmaktadır (Şekil 10).
Mineralojik analizlere göre deneyde kullanılan örnekler genel olarak anhidrit, dolomit ve kil minerallerinden (simektit, illit ve klorit) oluşmaktadır. Kil içeriğinin artmasıile anhidrit ve/ veya dolomit oranının azaldığ gözlenmektedir. Anhidrit ve dolomit kil matriks içerisinde birkaç mm'den birkaç cm'ye kadar boyutlarda damarlar ve nodüller şeklinde bulunabilmektedir. Kil minerallerinin \% 7-10 aralığından düşük (Tip I) ve yüksek (Tip II) olmasına göre iki şekilde sınıflanabileceği, mekanik deneylerden çıkan sonuçlarda oldukça belirgindir. 
Ündül, Amann, Kaiser

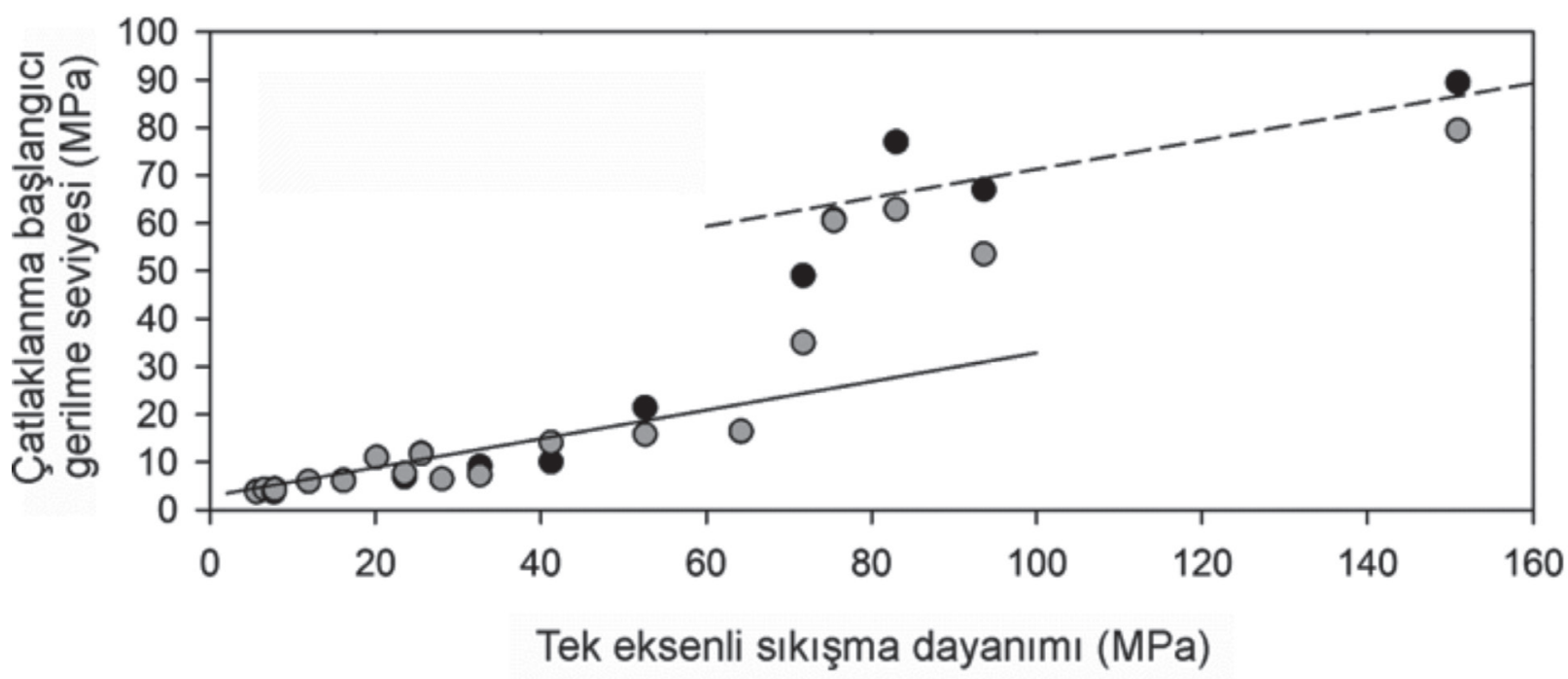

Şekil 10. Eksenel yük ile tek eksenli dayanımın çatlaklanma başlangıcı seviyesindeki ilişkisi. Koyu renkli noktalar, Brace vd. (1966) tarafından önerilen hacimsel şekil değiştirme yöntemine göre bulunmuştur. Açık renkli noktalar ise Lajtai (1974)'ün önerdiği yanal şekil değiştirme yöntemi ile bulunmuştur.

Figure 10. Uniaxial compressive strength in relation to the axial stress at the crack initiation stress point with darker colors are determined from the volumetric strain response according to Brace et al. (1966); points with lighter colors are determined from the radial strain response according to Lajtai (1974)

Şekil 11a'da kil içeriğine göre Tip I, Tip II ve geçiş zonlarına ait ince kesit görüntüleri bulunmaktadır. Kil matris kahverengi ve yer yer gri renklerden siyaha doğru renkler vermektedir. Açık gri kesimlerde anhidrit kristalleri bulunmaktadır. Siyah ve koyu renklerin hakim olduğu kesimler tamamen kil minerallerinden oluşmuş kesimlerdir. Farklı oranlarda kil ve anhidrit bileşimleri tek bir örnek içerisinde pek çok yerde gözlenmektedir. $\sigma_{C I}$ değerlerindeki değişimler kil matriksin mikro yapısal ve mineralojik değişimleri ile yakından ilişkilidir. Bu durum Şekil 11a ile uyumludur. Şekil 11b'de ise tek eksenli sıkışma deneyi sonrasında (yük doğrultusu oklar ile gösterilmiştir) yüke paralelyarı paralel gelişen kırıklar gözlenmektedir. Burada nispeten daha yumuşak kil matris içerisinde kırıklar gelişmekte, sağlam sert anhidrit damarlara kadar gelișen kırıklar sınır kırıkları olarak devam etmektedir. Artan yük ile kırıkların sert anhidrit damarları kestiği de düşünülmektedir.

Kil içeriğinin \%20'den fazla olduğu durumlarda, tek eksenli sıkışma dayanımının 20 MPa'dan 5 MPa'ya kadar düştüğü gözlenmektedir. Kil içeriğindeki artış \% 7-10 seviyelerini aştığında ise $\sigma_{C I}$ değerinin çok az bir değişim gösterdiği gözlenmektedir. Ayrıca Tip I kil içeriğinde, $U C S$ ve $\sigma_{C I}$ değerlerinin önemli bir şekilde arttığı belirgindir. Bu bölgede anhidrit ve dolomitin arttığı göz önünde bulundurulmalıdır. Kil minerallerinin diğer bileşenlere göre oransal değiminin UCS ve $\sigma_{C I}$ üzerindeki etkileri Şekil 12'de gösterilmektedir. 

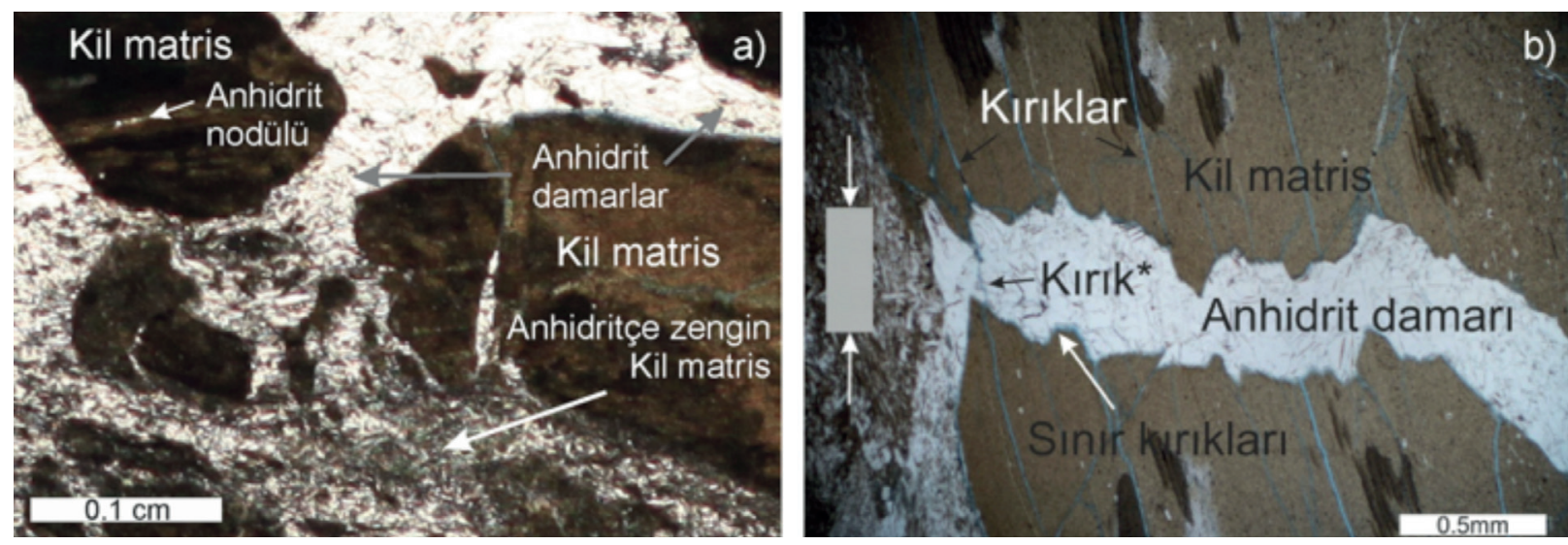

Şekil 11. Mekanik deneylerde kullanılan örneklerin iç yapılarını gösteren ince kesit görüntüleri a) Mekanik deney öncesi bir örneğe ait görüntü, b) Tek eksenli deney sonrası örneğe ait görüntü.

Figure 11. Thin sections showing the micro-texture of specimen used in mechanical tests a) a view of a specimen before the mechanical test, b) a view of a specimen after in the mechanical tests.
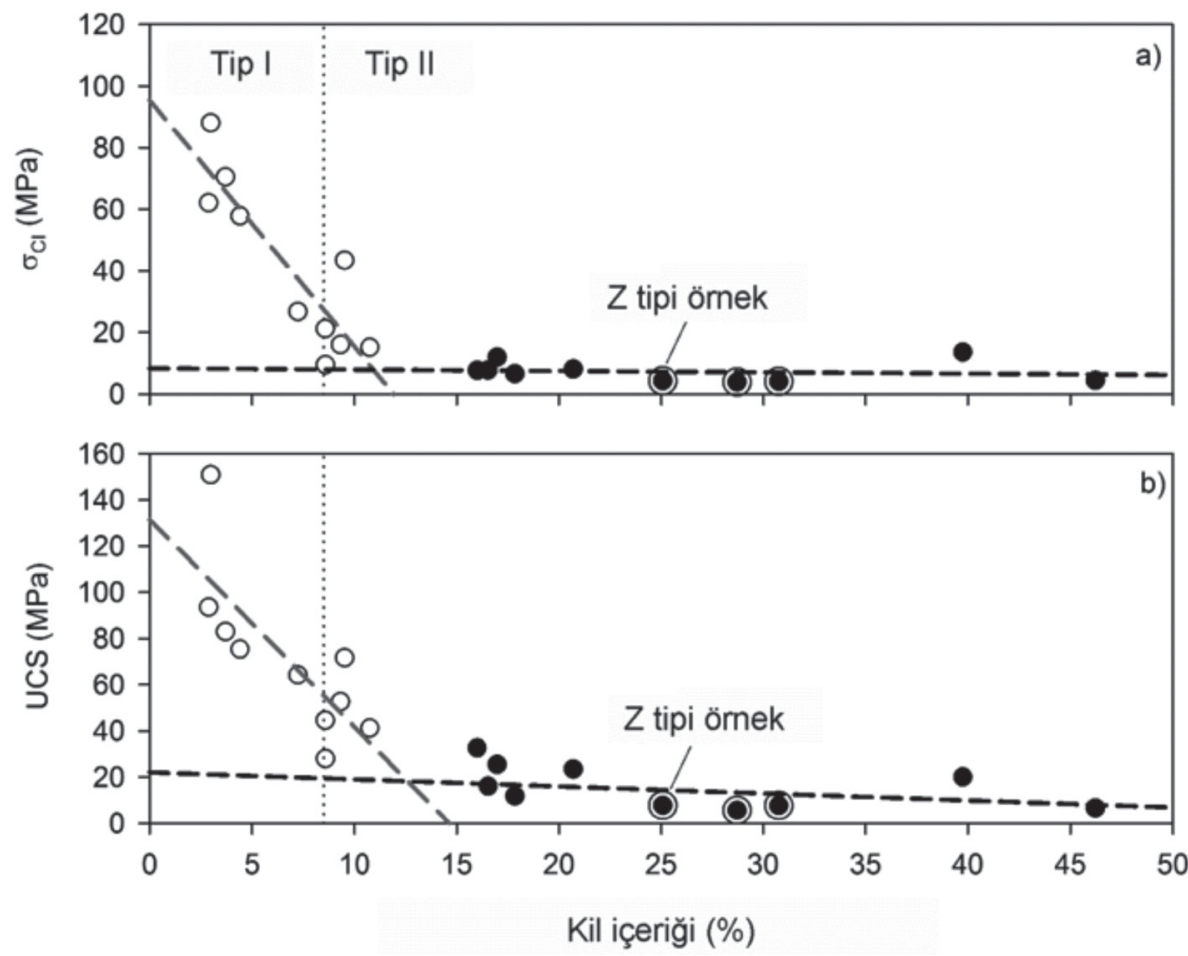

Şekil 12. Kil minerallerinin toplam içeriği ile a) çatlaklanma başlangıcı gerilme seviyeleri $\left(\sigma_{\mathrm{CI}}\right)$, ve b) çevre gerilmesiz sıkışma dayanımı (UCS) değerleri arasındaki ilişki. Z tipi örnekler çift halka ile gösterilmiştir. Şeklin a kısmında verilen çatlaklanma başlangıcı gerilme seviyeleri Brace vd. (1966)'ya göre tespit edilmiştir.

Figure 12. The relation between total content of clay and a) crack initiation stress level $\left(\sigma_{\mathrm{CI}}\right)$ and b) uniaxial compressive strength. Type $Z$ specimens are highlighted by doublecircle. The crack initiation stress levels in (a) are determined by the method proposed by Brace et al (1966). 
Ündül, Amann, Kaiser

Tip II'nin olduğu bölgelerde, $\sigma_{C I}$ değerlerindeki küçük sapmalar, mikrokırıkların gelişimini oluşturacak fark gerilmeler, yaklaşık olarak sabittir. Tip I'de $\sigma_{\text {CI }}$ 'n artışı kil matriks içerisinde anhidritin artması ile açıklanmaktadır. Farklı kil matris türlerinin olması ve Tip I'deki anhidrit içeriğinin artması, Tip I ve II arasındaki geçiş zonlarında, $\sigma_{C I}$ 'in neden farklı olduğunu açıklamaktadır.

Tip I örneklerde, UCS artışı, kil matriksin dayanımının, içerisinde saçılmış halde bulunan anhidrit miktarının artışına bağlı olarak (nispi olarak kil içeriğinin azalması) yükselmesi ile açıklanabilir.

$75 \mathrm{MPa}$ 'dan büyük tek eksenli sıkışma dayanımı (H örnekleri) gösteren örneklere ait $\sigma_{C I}$ değerleri 3:10 oranında artmaktadır (Şekil 10). Bu örnekler Tip II ve geçiş zonundaki örneklerden çok farklı bir doku sunmaktadır. $\mathrm{Bu}$ örneklerde kil içeriğgi \% 5'ten düşüktür ve neredeyse homojen bir görünüm sunmaktadır. $\mathrm{Bu}$ sebeple çatlak gelişimi, farklı iç yapıdaki örneklerin bir arada bulunduğu örneklerden çok homojen bir anhidritin çatlaklanma seviyelerine daha yakındır.

\section{Tek eksenli sıkışma deneylerinde yenilme süreçleri}

Tek eksenli sıkışma deneylerinde yenilme süreçlerinin tanımlanması, mekanik deneyler sonrasinda karot örneklerinden alınan ince kesitler üzerinde yapılan çalışmalar ile gerçekleştirilmiştir. $\mathrm{Bu}$ çalışmalarda, UCS dayanımı $80 \mathrm{MPa}$ 'ı üzerinde ve kil içeriği \% 5'ten fazla olan örnekler değerlendirilmiştir. $\mathrm{Bu}$ örneklerde, daha önce de bahsedildiği gibi, kil matriks içerisinde farklı oranlarda saçılmış anhidrit damarları heterojen yapıyı oluşturmaktadır.

İnce kesitlerde pek çok mikroçatlak gözlenmektedir (Şekil 8c ve d). Mikroçatlaklar genellikle yük eksenine paralel ve yarı paralel olarak bulunmaktadırlar. Farklı açılardaki çatlak gelişimi ise, mikroyapıdaki değişiklikler ve heterojenlikle ilgilidir. Gözlenen kırık türlerinden bir tanesi de sınır kırıklarıdır (Örn: kil matriks ve heterojenliği oluşturan unsurlar arasında). Sınır kırıkları genel olarak anhidrit damarları, nodülleri ve anhidritçe zengin matriks ile kil matriks arasında gelişmektedir. Bazı durumlarda mikroçatlakların sert anhidrit damarlarını kestiği de gözlenmiştir. Anhidritin ve anhidritçe zengin kil matriksin nispeten daha dayanıml olmasından dolayı bu çatlakların, sınır kırıklarına göre daha yüksek gerilme seviyelerinde oluştuğu öngörülmektedir.

Mikroçatlaklar, kil matriks içerisinde asal yüklere paralel olarak açılma eğilimindedir. $\mathrm{Bu}$ durum, yanal deformasyon artışını da beraberinde getirmektedir. Çevre gerilmesiz yük koşullarında, gözle görülebilir boyutta eksenel kırıklar genellikle gevrek kayalarda, düşey yüklerin kararsız kırık gelişimi gerilme seviyesini geçtiği seviyelerde gözlenmektedir. (Bieniawski, 1967; Martin, 1997). Ancak bu heterojen iç yapı özelliğindeki sülfatça zengin killi kayalarda yapılan deneylerde, herhangi bir yüksek dayanım ya da gözle görülebilen kırıklar tespit edilememiştir. Sadece, kil içeriği $\% 5$ 'ten az olan homojen nitelikli örneklerde 
bu kırıklar gözlenmiştir. Mikro ve makro ölçekte yapılan bu gözlemler, mikroçatlakların, heterojen örneklerde tek bir yerde birikmediğ $i$ ve devamında da yenilme öncesinde gözle görülebilen boyutlarda kırıkların gelişmediği sonucunu ortaya koymaktadır. Bu süreç büyük olasılıkla, kırıkların gelişmesini engelleyen ve bunları tutan anhidrit damarlarının yönelimine, miktarına ve dağılımına bağlıdır. Bu sebeple, diğer gevrek kayalarda yenilme sırasında veya hemen öncesinde gözlenen makro kırklar, bu tip heterojen iç yapı özelliği olan kayalarda gözlenmemektedir. $\mathrm{Bu}$ heterojen iç yapı aynı zamanda farklı gerilme seviyelerindeki ani gerilme düşüşlerini de açıklamaktadır (Şekil 13a ve b).

Yukarıdaki yorumlara göre, heterojen yapıya sahip örneklerde gelişen kırıkların anhidrit

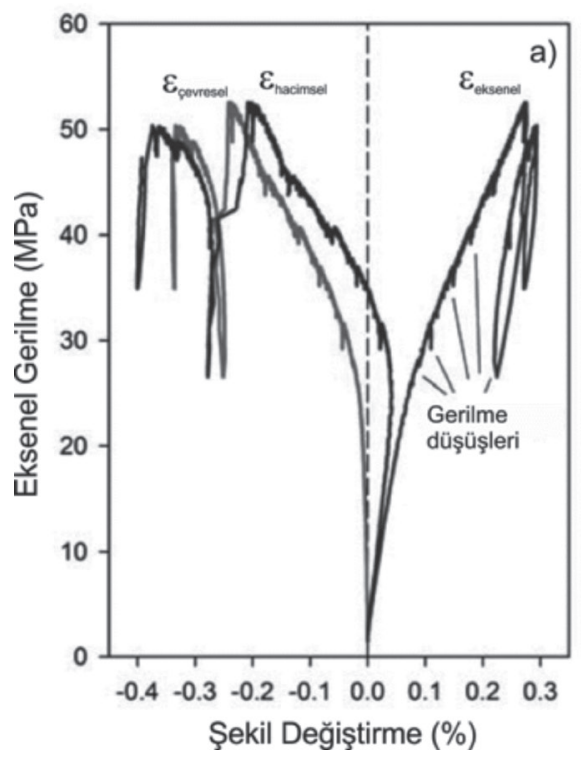

damarları tarafindan tutulduğu ve bu durumun da anhidrit damarlarının sıklığı, yönelimi ve dağılımı ile yakından iligili olduğu belirgindir. Yüksek kil içeriğinin olduğu durumlarda, makroskopik kırık gelişmesi olasılığı, anhidtrit damarları olan örneklerden daha yüksektir. Bu nedenle, artan anhidrit damar yoğunluğundan dolayı, tekil kırıklar veya mikroçatlaklanma bölgeleri, düşük gerilme koşullarında birleşemezler ve son süreçte, kırıklar, artan gerilmelere bağlı olarak heterojen yapıları keserler. $\mathrm{Bu}$ durum, kil içeriğinin artmasıyla veya anhidrit içeriğinin azalmasıyla dayanımın azalması durumunu açıklamaktadır. Böylece, zayıf kil içerikli ama yüksek anhidrit bileşimli örnekler, düşük çatlaklanma başlangıcı gerilme seviyeleri gösterse de yüksek dayanım gösterebilirler.

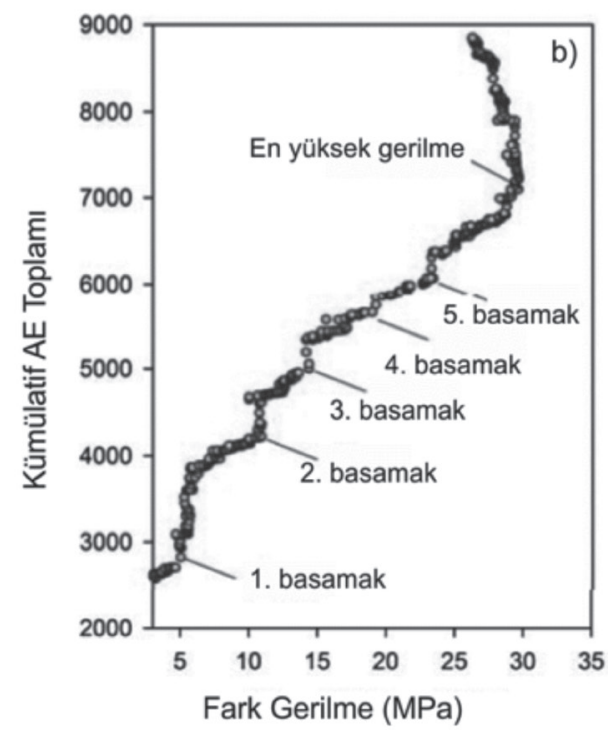

Şekil 13. Heterojen örneklere ait (Tip II ile Tip I ve Tip II arası geçiş örnekleri) a) Tek eksenli deney sonuçlarına göre çizilen gerilme şekil değiştirme grafiği b) Üç eksenli deneylerde mikro ses aktivitesine göre elde edilen grafik.

Figure 13. The graphs for heterogeneous specimen (Type II and transition specimen between Type I and Type II) a) stress-strain diagram obtained from uniaxial compressive strength test b) the graph obtained from acoustic emission during the triaxial strength test. 
Ündül, Amann, Kaiser

\section{Çevre gerilmeli deneyler ve yenilme süreçleri}

Üç eksenli deneyler, heterojen yapılı örnekler üzerinde gerçekleştirilmiştir. 15 adet üç eksenli deney sonucuna ait veriler Çizelge 4'te sunulmuştur. Deneyde kullanılan örneklerin mineralojik içerikleri ise Çizelge 5 'te verilmektedir. Üç eksenli deneylerdeki örneklerin kil içerikleri \% 6.7 - 33.8 arasında değişmektedir. Böylece örneklerin, Tip II’ye veya Tip I ile Tip II arasındaki geçiş seviyelerine ait olduğu anlaşılmaktadır (Şekil 12).
Üç eksenli sıkışma etkisinde, Şekil 13a'da asal gerilme ve Şekil 14b'de deviatör gerilmelere göre, $\sigma_{C I}$ seviyelerinin ilişkileri gösterilmektedir. Her iki grafikte çatlaklanma başlangıcı mikro ses aktivitesi ve hacimsel şekil değiştirme tepkisine göre belirlenmiştir. Artan çevre gerilmeleri ile çatlaklanma başlangıcındaki eksenel gerilme çok hafif bir eğimle artma eğilimindedir. Ancak fark gerilme çevre gerilmesinden bağımsız olup yaklaşık 4 - $8 \mathrm{MPa}$ arasında değişmektedir. Bunun yanında, Z örneklerinde, çatlaklanma başlangıcı

Çizelge 5. Üç eksenli sıkışma dayanımı testlerinde kullanılan örneklere ait XRD verileri.

Table 5. XRD data of the specimen used in triaxial compressive tests.

\begin{tabular}{|c|c|c|c|c|c|c|c|c|}
\hline $\begin{array}{c}\text { Kuyu } \\
\text { Numara } \\
(-)\end{array}$ & Derinlik & $\begin{array}{l}\mathrm{Ah} \\
(\%)\end{array}$ & $\begin{array}{l}\text { Gy } \\
(\%)\end{array}$ & $\begin{array}{l}\mathrm{Ba} \\
(\%)\end{array}$ & $\begin{array}{l}\text { Do } \\
(\%)\end{array}$ & $\begin{array}{c}\text { Q } \\
(\%)\end{array}$ & $\begin{array}{l}\mathrm{Mg} \\
(\%)\end{array}$ & $\begin{array}{l}\text { CM } \\
(\%)\end{array}$ \\
\hline B4 & 330 & 76.0 & 0 & 0 & 0 & 2.7 & 5.8 & 10.94 \\
\hline B1 & 270 & 78.72 & 0.26 & 1.09 & 0.2 & 2.17 & 18.85 & 9.33 \\
\hline B3 & 249 & 54.4 & 0 & 1.23 & 0 & 6.35 & 13.57 & 13.72 \\
\hline B4 & 267 & 67.0 & 0.34 & 1.3 & 0 & 5.31 & 10.85 & 9.21 \\
\hline B4 & 335 & 63.1 & 1.34 & 0.52 & 0 & 5.67 & 7.01 & 13.31 \\
\hline B4 & 335 & 63.1 & 1.34 & 0.52 & 0 & 5.67 & 7.01 & 13.31 \\
\hline B4 & 405 & 27.1 & 0 & 3.9 & 0 & 7.01 & 20.09 & 33.81 \\
\hline B3 & 440 & 54.4 & 0 & 0 & 0 & 4.06 & 13.71 & 20.4 \\
\hline B4 & 275 & 67.0 & 0.34 & 1.3 & 0 & 5.31 & 10.85 & 9.21 \\
\hline B3 & 455 & 70.3 & 0 & 1.48 & 0 & 2.45 & 8.81 & 11.49 \\
\hline B3 & 245 & 70.15 & 0.31 & 1.51 & 0.04 & 2.61 & 10.12 & 9.36 \\
\hline B3 & 231 & 55.5 & 0.43 & 1.1 & 0 & 6 & 18.71 & 9.87 \\
\hline B3 & 227 & 56.5 & 0.22 & 1.24 & 0 & 4.83 & 23.54 & 7.23 \\
\hline B5 & 505 & 71.4 & 0 & 0.17 & 0 & 5.07 & 13.32 & 6.7 \\
\hline B4 & 495 & 68.8 & 0.78 & 1.52 & 0 & 4.51 & 11.39 & 6.84 \\
\hline
\end{tabular}

Ah: Anhidrit; Gy: Jips; Ba: Basanit; Do: Dolomit; Q: Kuvars; Mg: Manyezit; CM: Kil mineralleri. (Smektit, illit ve klorit minerallerinin toplamı verilmiştir.) 

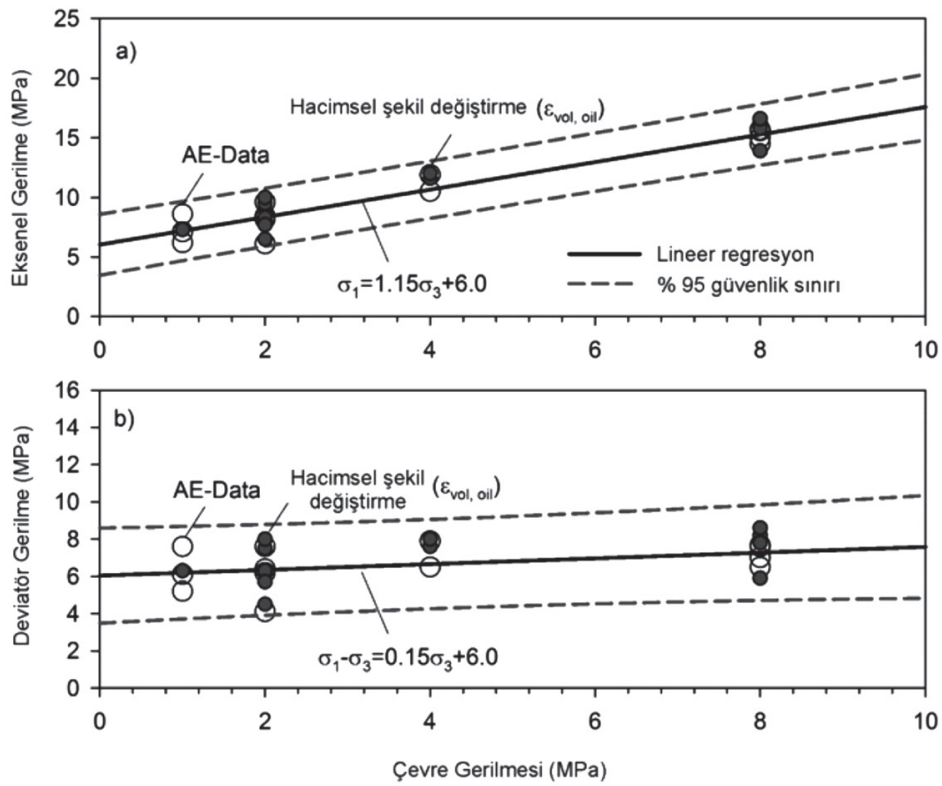

Şekil 14. Üç eksenli sıkışma koşulları altında çatlaklanma başlangıcı değerleri a) asal gerilmelere ait diyagram b) deviatör gerilmelere göre elde edilen diyagram.

Figure 14. The crack initiation stress levels under traixial compressive conditions a) the graph for major stresses b) the graph for deviatoric stresses.

gerilme seviyelerindeki fark gerilmeleri $\mathrm{P}$ ve $\mathrm{F}$ örneklerinde elde edilen gerilme seviyelerine çok yakındır. Bu durum, kil içeriğinin, \% 7’yi geçtiği durumlarda yük doğrultusunun tabakalanma düzlemine göre konumu arasında çok az bir ilişkinin olduğunu göstermektedir. Kil içeriğinin $\% 7$ - 10 aralığından fazla olduğu örneklerde, üç eksenli ve tek eksenli deneylerde elde edilen çatlaklanma başlangıcı değerleri birbirleri ile uyumludur. Benzer sonuçlar Amann vd. (2011) tarafından Opalinus Killeri üzerinde yapılan bir çalışmada da sunulmuştur.

$\mathrm{Bu}$ çalışmadan elde edilen mikro ses aktiviteleri, artan fark gerilmeleri ile basamaklı bir yap1 göstermektedir (Şekil 13b). Gevrek kayalar üzerinde yapılan önceki çalışmalarda, devamlılık gösteren ses aktiviteleri gözlenmektedir
(Eberhardt vd., 1998; Mogi, 1962). Burada gözlenen basamaklı yapı daha önce tek eksenli deneylerde gözlenen ve nedenleri açılanan gerilme düşüşleri ile aynı sebepten dolayı oluşmaktadır. Ancak çevre gerilmeli deneylerde eksenel kırıklar ile beraber makaslama kırıklarının geliştiği de unutulmamalıdır.

Her iki grafikte de çatlaklanma başlangıcı değerleri, mikro ses aktivitesine (içi boş yuvarlaklar) ve hacimsel şekil değiştirmeye göre (siyah yuvarlaklar) elde edilmiştir.

Tek eksenli sıkışma deneyleri, kaya dayanımının, öncelikle kil minerallerinin kütlece oranına, ardından anhidrit damarlarının dağılımına ve yönelimine bağlı olduğunu ortaya koymaktadır. Kil içeriğinin \% 20'den 
Ündül, Amann, Kaiser

yüksek olduğu örneklerde, deney örneğinin iç geometrisinin dayanıma etkisi azdır. Üç eksenli deneylerde kullanılan örneklerde kil içeriği \% 6.7 ile \% 33.8 arasında değişmektedir.

\section{ELDE EDİLEN VERILERIN YERALTI KAZILARINDAKİ ÖNEMI}

Masiften orta dereceli kırıklıya kadar farklı kaya özelliği gösteren kaya kütlelerinde açılan tünellerin çevresindeki düşük çevre gerilmesi olan bölgelerdeki kaya kütlesinin dayanımı, laboratuvarda elde edilen ve öngörülen değerlerden oldukça düşüktür (Martin, 1997; Kaiser vd., 2010; Diederichs, 2003). Bu düşük çevre gerilmeli ortamlarda gözle görülebilen boyutta çatlakların gelişmesi için gereken gerilme seviyelerinin, çatlaklanma başlangıcı gerilme seviyeleri ile eşdeğer olduğu ortaya konmuştur (Martin, 1997; Kaiser vd., 2010; Diederichs, 2003). Diğer bir ifade ile çatlaklanma başlangıcı gerilme seviyelerinin hemen üzerindeki gerilme seviyeleri, kavlaklanmalara ve kopmalara sebep olabilmektedir. Sülfatça zengin killi kayalarda farklı boyutlarda sert ve dayanımlı heterojen yapılar bulunmaktadır. Örneğin Gipskeuper formasyonunda anhidritten oluşan pekçok heterojenlik yaratan unsur bulunmaktadır. Anhidrit damarları ve tabakalarının kalınlıkları $\mathrm{mm}$ ölçeğinden $\mathrm{cm}$ ölçeğine kadar olan boyutlardadır. Bu çalışmada elde edilen bulgular, çatlaklanma başlangıcı gerilme seviyelerinin, kavlaklanma, kopma gibi kaya kütlesini parçalayıcı etkilere sebebiyet verecek, çatlak gelişimini başlatıcı gerilme seviyeleri olarak düşünülmemesi gerektiğini ortaya konmuştur. Çünkü sert ve dayanımlı heterojen yapılar (damarlar ve tabakalar), gelişen çatlakların açılmasını ve ilerlemesini engelleyici yönde rol oynamaktadırlar. Böylece kaya kütlesinin ani bir şekilde dağılmasını engellerler. Bunu yanında, Alonso ve Berdugo (2008) tarafından önerildiği gibi, tüneller çevresindeki kazı etki zonundaki fissürler ve çatlaklar, sülfatça zengin yeraltı sularının buralarda aşırı doygun hale gelmesi ile yeni kristallarin gelişmesine bağlı olarak şişme ve kabarmalara yol açabilir. Bu çalışma kapsamında sülfatça zengin killi kayalarda yapılan değerlendirmeler, tünel çevresindeki düşük çevre gerilmeli alanlarda gelişen mikro kırıklanmaların gelişebileceğini ve jips çökelimini arttırıcı etki yapabileceğini göstermektedir.

\section{SONUÇLAR}

Sülfatça zengin killi kayaların yenilme davranışlarını belirlenmesi için tek eksenli ve üç eksenli gerilme koşulları altında bir seri deney yapılmıştır. Deneyler sırasında kullanılan örnekler Belchen (İsviçre) Otoyol Tünelleri drenaj galerilerinden elde edilmiştir. $\mathrm{Bu}$ deney sonuçlarına göre, mikroçatlaklar ilk olarak kil matriks içerisinde 4 - $13 \mathrm{MPa}$ arasında değişen deviatör gerilmelerde oluşmaktadır. Kil içeriği \% 7'den büyük olan örneklerde çatlaklanma başlangıcı seviyesindeki gerilmeler örnek geometrisinden ve çevre gerilmelerinden bağımsızdır. Mikroyapısal ve mineralojik değişkenlikler, kil matriksin dayanım ve sertlik farklılıklarını oluşturmaktadır. Bu heterojenlikler, 
eksenel yüklemelerde gerilme ve şekil değiştirme farklılıklarını geliştirmektedir. Bunun sonucunda da yersel yenilmeler gözlenmektedir. Gerilme şekil değiştirme diyagramlarındaki ani gerilme düşmeleri ve mikro ses aktivitesindeki basamaklı yapılar bu durumu destekler niteliktedir.

Karot örneği ölçeğinde, mikroçatlaklar düşük deviatorik gerilmelerde gelişmekte ancak çatlak gelişimi çoğunlukla Anhidrit damarlar tarafindan sinırlandırılmaktadır. $\mathrm{Bu}$ damarların duraysız çatlak oluşumunu da engelediği düşünülmektedir. Anhidrit damarların yoğunluğu, yönelimi ve sıklığına bağlı olarak, çatlakların birbirleri ile birleşerek yenilmeyi gerçekleştirebilmesi için sınır kırıklarının ve anhidriti kesen çatlakların oluşmasından daha yüksek seviyelerde gerilmelere ve şekil değiştirmelere ihtiyaç duyulmaktadır.

Düşük deviatorik gerilemelerde çatlak başlangıcı, bu sebeplerden dolayı kil matrikse bağlıdır. Sülfatça zengin killi kayalar farklı ölçeklerde anhidrit damarları içerebilmektedir. Tünel ölçeğinde Anhidrit tabakaları ve damarları, gelişen çatlak ve kırıkları tutarak kaya kütlesinin dağılmasını engeleyebilmektedir. Kaya kütlesi çatlaklanma başlangıcı gerilme seviyesinden sonra yenilebilecekken, gelişen çatlakların tutulmasından dolayı hızlı gelişen duraysızlık sorunlarının oluşmayabileceği düşünülmektedir.

\section{KAYNAKLAR}

Alonso, E., Berdugo, I.R., 2005. Expansive behaviour of sulphate-bearing clays. International Conference on Problematic soils, Famagusta, edited by Bilsel and Nalbantogu, Eastern Mediterranean University Press, 477-498.

Alonso, E., Berdugo, I.R., 2008. Degradation and swelling of sulphate-bearing claystones. VI CSAMR 2006, Cartanga de Indias, edited by Montero and Colmenares, 211-248.

Amann, F., Ündül, Ö., Kaiser, P. K., 2013a. Crack initiation and crack propagation in heterogeneous sulfate-rich clay rocks. Rock Mechanics and Rock Engineering, 47 (5), 1849-1865.

Amann, F., Ündül, Ö., Löw, S., Kaiser, P. K., 2013b. Fracture processes and in-situ fracture observations in Gipskeuper. Eidgenössisches Departement für Umwelt, Verkehr, Energie und Kommunikation (UVEK) und Bundesamt für Strassen (ASTRA), 1422.

Amann, F., Button, E. A., Evans, K. F., Gischig, V. S., Blümel, M., 2011. Experimental study of the brittle behavior of clay shale in short-term unconfined compression. Rock Mechanics and Rock Engineering, 44 (4), 415-430.

Amstad, C., Kovari, K., 2001. Untertagbau in quellfähigem Fels, Eidgenössisches Department für Umwelt, Verkehr, Energie und Kommunikation (UVEK) \& Bundesamt für Strassen (ASTRA), Zürich

Anagnostou, G., Pimentel, E., Serafeimidis, K., 2010. Swelling of sulphatic claystones - some fundamental questions and their practical relevance. Geomechanics and Tunnelling, 3 (5), 567-572. 
Ündül, Amann, Kaiser

Bieniawski, Z. T., 1967. Mechanism of brittle failure of rock Part I - Theory of fracture process. International Journal of Rock Mechanics and Mining Science, 4 (4), 395-406.

Berdugo, I. R., Alonso, E. E., Morales, E., Solé, A., 2009. Tunnelling and Swelling in Triassic Sulphate-Bearing Rocks. Part I. Case studies from Baden-Württemberg. Revista Épsilon N. ${ }^{\circ}$ 12: $13-37$.

Brace, W. F., Paulding, B. R., Scholz, C., 1966. Dilatancy in fracture of crystalline rocks. Journal of Geophysical Research, 71 (16), 3939-3953.

Diederichs, M. S., 2003. Rock fracture and collapse under low confinement conditions. Rock Mechanics and Rock Engineering, 36 (5), 339381.

Eberhardt, E., Stead, D., Stimpson, B., Read, R. S., 1998. Identifying crack initiation and propagation thresholds in brittle rock. Canadian Geotechnical Journal, 35, 222-233.

Fairhurst, C., Cook, N. G. W., 1966. The phenomenon of rock splitting parallel to the direction of maximum compression in the neighborhood of a surface. Proceedings $1^{\text {th }}$ Congress of the International Society of Rock Mechanics, Lisbon, 687-692.

Grob, H., 1972. Schwelldruck im Belchentunnel. Proceedings of International Symposium on Underground Opening, Luzern, 99-119.

Grob, H., 1976. Swelling and heave in swiss tunnels. Bulletin of International Association of Engineering Geologists, 13, 55-60.

Hallbauer, D. K., Wagner, H., Cook, N. G. W., 1973. Some Observation Concerning The Microscopic And Mechanical Behaviour of Quartzite Specimens In Stiff, Triaxial Compression Tests. International Journal of Rock Mechanics and Mining Science, 10, 713-726.
IGT (Istitut für Geotechnik-ETH), 1995. Hauenstein BasisTunnel - Wisenberg Tunnel, Laboruntersuchungen, Bericht Nr. 4383/9.

ISRM, 1979. Suggested Methods for Determining the uniaxial compressive strength and deformability of rock materials. International Journal of Rock Mechanics and Mining Science, 16 (2), 135-140.

Kaiser, P. K., Kim, B. H., 2008. Rock Mechanics Challenges in Underground Construction and Mining. $1^{\text {th }}$ Southern Hemisphere International Rock Mechanics Symposium, Australia, edited by Potvin, Carter, Dyskin and Jeffery, 23-38.

Kaiser, P. K., 2010. How highly stressed brittle rock failure impacts tunnel design. Eurock, 27-38.

Lajtai, E. Z., 1974. Brittle fracture in compression. International Journal of Fracture, 10 (4), 525536.

Lockner, D. A., Moore, D. E., Reches, Z. 1992. Microcrack interaction leading to shear fracture. 33rd U.S. Rock Mechanics Symposium, edited by Tillerson and Wawersik, Balkema, Rotterdam, 807-816.

Madsen, F. T., Nüesch, R., 1991. The swelling behaviour of clay-sulfate rock. 7th International Congress on Rock Mechanics, Aachen, Germany, 285-288.

Madsen, F. T., Flückiger, A., Hauber, A., Jordan, L., Vögtli, B., 1995. New investigations on swelling rocks in the Belchentunnel Switzerland. 8th International Congress on Rock Mechanics, Tokyo, 1, 263-267.

Martin, C. D., 1997. Seventeenth Canadian Geotechnical Colloquium: The effects of cohesion loss and stress path on brittle rock strength. Canadian Geotechnical Journal, 34, 698-725. 
Martin, C. D., Chandler, N. A., 1994. The progressive fracture of Lac du Bonnet granite. International Journal of Rock Mechanics and Mining Science, 31, 643-659.

Mogi, K., 1962. Study of elastic shocks caused by the fracture of heterogeneous materials and its relations to earthquake phenomena. Bulletin of the Earthquake Research Institute, 40, 125-173.

Nicksiar, M., Martin, C. D., 2012. Evaluation of methods for determining crack initiation in compression tests on low-porosity rocks. Rock Mechanics and Rock Engineering, 45 (4), $607-$ 617.

Nicksiar, M., Martin, C. D., 2013. Factors affecting crack initiation in low porosity crystalline rocks. Rock Mechanics and Rock Engineering, 47 (4), 1165-1181.

Oğuzberk, U. C., 2010. Gezende Barajı Enerji Tünelinde Su Kaçakları ve Onarım Çalışmalarının Değerlendirilmesi. İstanbul Yerbilimleri Dergisi, 23 (2), 109-120.

Scholz, C. H., 1968. Experimental study of the fracturing process in brittle rock, Journal of Geophysical Research, 73 (4), 1447-1454.

Steiner, W., 1993. Swelling rock in tunnels: Characterization, effect of horizontal stresses and construction procedure. International Journal of Rock Mechanics and Mining Science, 30 (4), 361-380.

Steiner, W., Metzger, R., 1988. Erfahrungen aus Tunneln im quellenden Gestein, Experience from tunnels in swelling rocks. Internal report to Swiss Railways for Project Wisenbergtunnel.

Steiner, W., Kaiser, P. K., Spaun, G., 2010. Role of brittle fracture on swelling behavior of weak rock tunnels: hypothesis and qualitative evidence. Geomechanics and Tunnelling, 3 (5), 583-596.

Steiner, W., Kaiser, P. K., Spaun, G., 2011. Role of brittle fracture on swelling behavior of weak rock tunnels: evidence from tunnelling case histories. Geomechanics and Tunnelling, 4 (2), 141-156.

Tapponier, P., Brace, W. F., 1976. Development of stress-induced microcracks in Westerly Granit. International Journal of Rock Mechanics and Mining Science, 13, 103-112.

Vögtli, B., Jordan, P., 1996. Quelldruckentwicklung in Ton- und Sulfatgesteinen. Schweizer Ingenieur und Architekt, 18, 16-180. 
